\title{
Dipeptidyl Peptidase IV (DPPIV/CD26)-Based Prodrugs of Hydroxy-Containing Drugs
}

\author{
Alberto Diez-Torrubia, ${ }^{[a]}$ Silvia Cabrera, ${ }^{[a]}$ Anne-Marie Lambeir, ${ }^{[b]}$ Jan Balzarini, ${ }^{[c]}$ María- \\ José Camarasa, ${ }^{[\mathrm{a}]}$ and Sonsoles Velázquez ${ }^{*[a]}$
}

\begin{abstract}
We previously described a novel prodrug approach in which a di- or tetrapeptide moiety is linked to a wide variety of aminecontaining drugs through an amide bond, which is specifically cleaved by dipeptidyl peptidase IV (DPPIV/CD26) activity. Herein we report the application of this prodrug approach to a variety of hydroxy-containing drugs (primary, secondary, tertiary, or aromatic hydroxy groups). We designed and studied tripartite prodrugs containing a dipeptide moiety (cleavable by DPPIV/CD26) and a valine as a hetero-bifunctional connector to link the dipeptide to the hydroxy group of the drug
\end{abstract}

through a metabolically labile ester bond. The hydroxy-containing prodrugs showed various susceptibilities to hydrolysis by DPPIV/CD26 and serum, depending on the nature of the compound. Prodrugs of compounds containing a primary hydroxy group (as in didanosine) or a hydroxy moiety on an aromatic entity (as in acetaminophen) were most efficiently converted. In contrast, a tertiary hydroxy group was much less susceptible to conversion into its parent drug by DPPIV/CD26 or serum. A number of the prodrugs showed remarkable increases in water solubility relative to their parent drugs.

\section{Introduction}

Many prodrug strategies/technologies have already been developed to overcome unfavorable pharmaceutical, pharmacokinetic, or pharmacodynamic properties of drugs of various natures. ${ }^{[1-3]}$ For hydroxy-containing drugs, the formation of esters is a common prodrug approach used today. For this purpose, coupling of amino acids as carriers of a therapeutic agent has previously been applied. Examples of amino acid coupling to drugs include valacyclovir ${ }^{[4]}$ and valgancyclovir, ${ }^{[5]}$ the valyl ester prodrugs of the anti-herpetic acyclovir and ganciclovir, respectively, as well as recent success with the valine derivative of highly specific anti-varicella zoster virus bicyclic nucleoside analogue Cf1743 (designated FV-100). ${ }^{[6]}$ These prodrugs have shown notably increased oral bioavailability due to their recognition by the human peptide transporter hPEPT-1 located in the membrane of the upper small intestinal epithelial cells. ${ }^{[7]}$ The conversion of amino acid prodrugs (with only one amino acid coupled through each ester bond) to the free therapeutic parental agent easily occurs through the action of ubiquitous esterases found in the blood, liver, and other organs and tissues. ${ }^{[8]}$ However, the stability of such prodrugs at physiological $\mathrm{pH}$ is low, and their delivery is often not optimal. ${ }^{[4]}$

The lymphocyte surface glycoprotein CD26 belongs to a unique class of membrane-associated peptidases and is identical to dipeptidyl peptidase IV (DPPIV). ${ }^{[9-11]}$ DPPIV/CD26 is a member of the prolyl oligopeptidase family, a group of atypical serine proteases able to hydrolyze prolyl bonds. It is endowed with an interesting dipeptidyl peptidase catalytic activity which selectively cleaves dipeptides when a proline or, to a lesser extent, an alanine is present at the penultimate position of the N-terminal end of a variety of natural peptides. A free, unsubstituted amino group on the terminal amino acid is essential for substrate recognition by the enzyme. ${ }^{[9,10]}$ In the human body, DPPIV/CD26 truncates several bioactive peptides of medical importance. ${ }^{[9,10]}$ The enzyme is expressed on a variety of cell types and is also detected as a soluble form in plasma and in low concentrations in cerebrospinal fluid. ${ }^{[12]}$

Balzarini et al. demonstrated for the first time that a synthetic and inactive small molecule (Gly-Pro-Gly- $\mathrm{NH}_{2}$ ) can be transformed into an active antiviral drug $\left(\mathrm{Gly}-\mathrm{NH}_{2}\right)$ through the specific action of DPPIV/CD26. ${ }^{[13]}$ Based on this study, we have reported a novel type of prodrug approach that could be applied to mediate the solubility, formulation, and bioavailability of therapeutic agents. ${ }^{[14-16]}$ In our approach, a di- or oligopeptide moiety (Xaa-Pro) ${ }_{n}$ was linked to the free amino group of a nonpeptidic drug through an amide bond which is specifically cleaved by the endogenous DPPIV/CD26 enzyme (Figure 1).

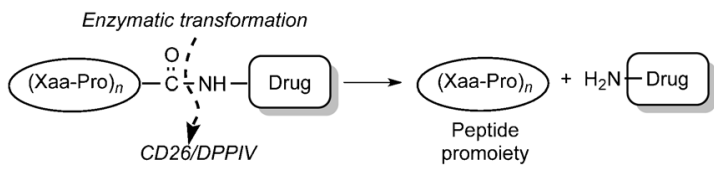

Figure 1. Prodrug approach based on DPPIV/CD26-driven peptide cleavage in amino-containing drugs.

[a] Dr. A. Diez-Torrubia, Dr. S. Cabrera, Prof. M.-J. Camarasa, Dr. S. Velázquez Instituto de Química Médica (C.S.I.C.)

Juan de la Cierva 3, 28006 Madrid (Spain) E-mail:sonsoles@iqm.csic.es

[b] Dr. A.-M. Lambeir

Laboratory of Medical Biochemistry, University of Antwerp

Universiteitsplein 1, 2610 Antwerp (Belgium)

[c] Prof. J. Balzarini

Rega Institute for Medical Research, KU Leuven

Minderbroedersstraat 10, 3000 Leuven (Belgium) 
The presence of a proline at the penultimate $\mathrm{N}$-position protects the amino acid sequence against nonspecific proteolytic degradation, as many exopeptidases do not recognize such amino acid sequences. ${ }^{[17]}$

This prodrug approach was successfully applied to a broad variety of compounds/drugs with a free amino group on an alkyl chain (e.g., the N-3 aminopropyl derivative of the anti-HIV TSAO compounds) ${ }^{[18,19]}$ or on heteroaromatic (6-aminoquinoline), carbohydrate (doxorubicin), heterocyclic pyrimidine (cytarabine), or purine rings (vidarabine). ${ }^{[14-16]}$

We recently applied this prodrug technology to the highly lipophilic antiviral drug family of bicyclic furanopyrimidine nucleoside analogues, specifically the Cf1743 analogue (Figure 2),

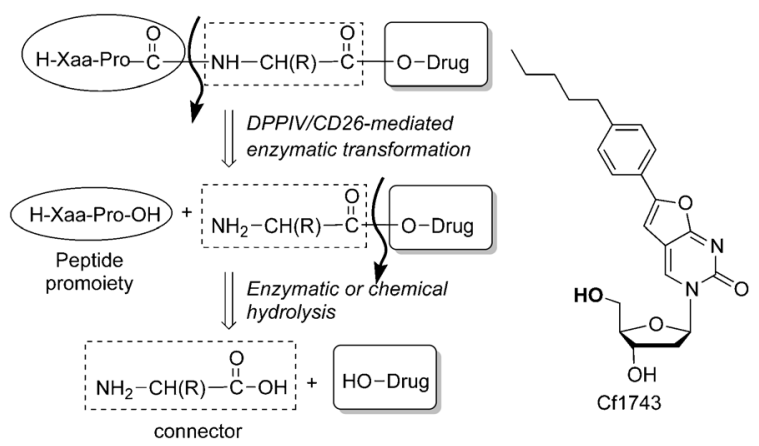

Figure 2. Prodrug approach based on DPPIV/CD26 for hydroxy-containing drug Cf1743.

to improve its physicochemical and pharmacokinetic properties. $^{[20]}$ In this hydroxy-containing drug, the peptidic sequence cannot be linked directly to the hydroxy group through an ester bond as the DPPIV/CD26 enzyme specifically recognizes free amide bonds. Thus, tripartite conjugates [Xaa-Pro]-[connector]-[drug] (Figure 2) were prepared and evaluated. In these conjugates, amino acids were chosen as hetero-bifunctional connectors to link the peptidic moiety to the hydroxy group of the drug. The liberation of the parent drug from such prodrugs takes place through a two-step hydrolysis sequence, involving the initial DPPIV/CD26-mediated enzymatic cleavage followed by chemical or enzymatic hydrolysis (i.e. by esterases) of the ester bond (Figure 2). Several prodrugs showed a remarkable increase in water solubility over the parent drug. We also demonstrated a markedly enhanced oral bioavailability of the prodrugs versus the parent drug in mice. ${ }^{[20]}$

With these promising results in hand, we considered extending the applicability of our prodrug strategy to a variety of hydroxy-containing drugs targeting various types of hydroxy groups as proof of concept of the methodology (Figure 3). For drugs containing primary hydroxy groups, the anti-HIV drug didanosine ${ }^{[21]}$ was chosen as an example of a polar purine nucleoside. As a hydroxy-containing aromatic compound, acetaminophen (paracetamol) was selected. The $\beta$-adrenergic receptor blocker propranolol ${ }^{[22]}$ and the anticancer drug camptothecin ${ }^{[23]}$ were chosen as examples for hydroxy-containing drugs bearing secondary and tertiary hydroxy groups, respectively. For the peptide pro-moiety, we used the Val-Pro dipep-

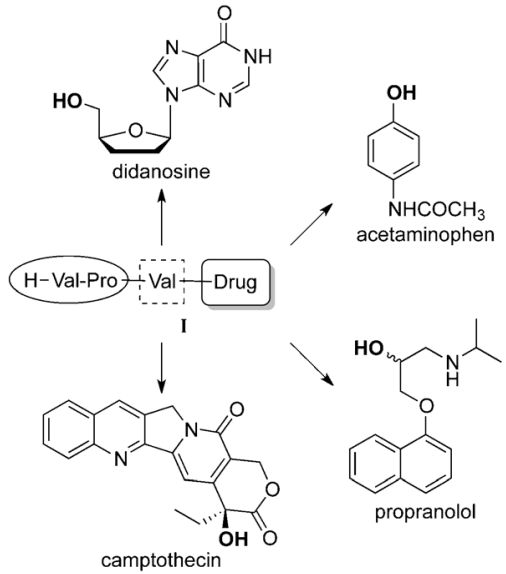

Figure 3. Structure of the target tripartite conjugates of the general formula [Val-Pro]-[Val]-[drug] (I).

tide prodrug sequence efficiently recognized by the DPPIV/ CD26 enzyme with the valine as a connector, based on the promising results obtained for the Cf1743 prodrugs. ${ }^{[20]}$ The synthesis, stability, and water solubility studies of target tripartite prodrugs of the general formula I (Figure 3), their ability to act as efficient substrates for DPPIV/CD26, and their human and bovine serum hydrolysis profiles is described herein.

\section{Results and Discussion}

\section{Chemistry}

The target prodrugs [Val-Pro]-[Val]-[drug] were obtained according to the general synthetic approach shown in Scheme 1. Specifically, the synthesis of these prodrugs was carried out using a combined sequence of $\mathrm{N}$-protected amino acid or dipeptide couplings followed by deprotection of the terminal amino group. We first synthesized the tripartite conjugates of the primary hydroxy group-containing drug didanosine. Because of the acidic instability of didanosine, we choose a basiclabile 9-fluorenylmethoxycarbonyl (Fmoc) protecting strategy (Scheme 2). Acylation at the 5'-position of didanosine with Fmoc-Val-OH was carried out in the presence of $N, N^{\prime}$-dicyclohexylcarbodiimide (DCC) and dimethylaminopyridine (DMAP) to afford the N-protected valyl ester derivative 1 in $94 \%$ yield. Treatment of 1 with piperidine in $N, N^{\prime}$-dimethylformamide (DMF) gave the unprotected [Val]-[didanosine] 2 in $80 \%$ yield.

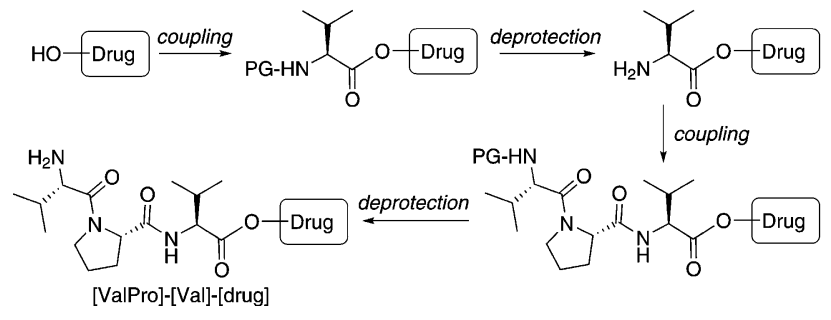

Scheme 1. General synthetic approach for the synthesis of tripartite conjugates. 


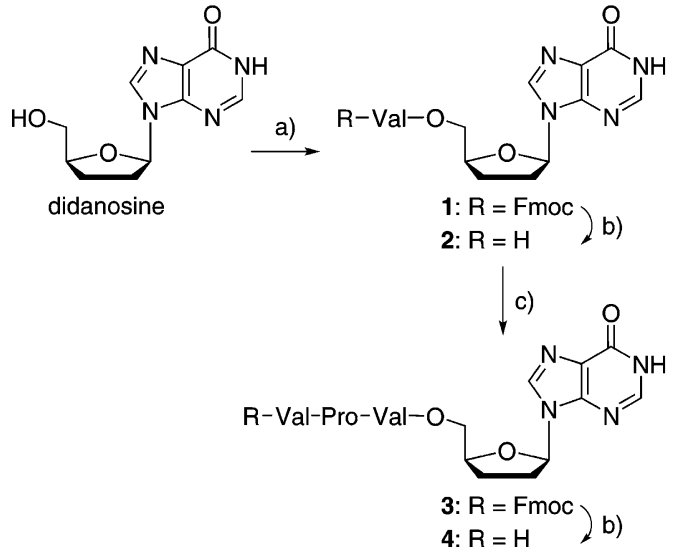

Scheme 2. Synthesis of the tripeptide prodrug of didanosine 4. Reagents and conditions: a) Fmoc-Val-OH, DCC, DMAP, DMF, 4 h, RT; b) $5 \%$ piperidine in DMF, 5 min, RT; c) Fmoc-Val-Pro-OH, BOP, TEA, $\mathrm{CH}_{2} \mathrm{Cl}_{2}, 15 \mathrm{~h}$, RT.

Next, compound $\mathbf{2}$ was reacted with the commercially available dipeptide Fmoc-Val-Pro-OH in the presence of (benzotriazol-1-yloxy)tris(dimethylamino) phosphonium hexafluorophosphate (BOP) and triethylamine (TEA), after which the N-terminal amino group was deprotected under basic conditions to yield the [Val-Pro]-[Val]-[didanosine] conjugate 4 in $50 \%$ overall yield.

Synthesis of the [Val-Pro]-[Val]-[acetaminophen] conjugate $\mathbf{8}$ is depicted in Scheme 3. Acylation of acetaminophen with Fmoc-Val-OH was carried out following the acylation procedure

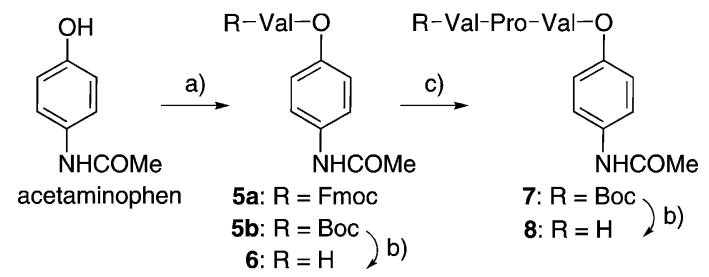

Scheme 3. Synthesis of [Val-Pro]-[Val]-[acetaminophen] conjugate 8. Reagents and conditions: a) Fmoc-Val-OH or Boc-Val-OH, DCC, DMAP, DMF, 2 h, RT; b) TFA, Et ${ }_{2} \mathrm{O}, 7 \mathrm{~h}, \mathrm{RT}$; c) Boc-Val-Pro-OH, BOP, TEA, $\mathrm{CH}_{2} \mathrm{Cl}_{2}, 15 \mathrm{~h}$, RT.

described above for didanosine and afforded the N-protected valyl ester derivative $\mathbf{5}$ a in $84 \%$ yield. Unfortunately, Fmoc-deprotection of $\mathbf{5} \mathbf{a}$ under basic conditions (5\% piperidine in DMF) yielded a complex mixture of products of which acetaminophen was the major compound. Next, synthesis of the unprotected [Val]-[acetaminophen] $\mathbf{6}$ was attempted through a tert-butoxycarbonyl (Boc) strategy. Coupling of acetaminophen with Boc-Val-OH in the presence of DCC/DMAP followed by acidic deprotection using trifluoroacetic acid (TFA) in diethyl ether gave the desired valyl derivative 6 as a trifluoroacetate salt in $74 \%$ overall yield. Reaction of 6 with Boc-Val-Pro-OH using standard coupling conditions (BOP/TEA) yielded the $\mathrm{N}$ protected tripeptide 7 in high yield (97\%). Finally, deprotection of $\mathbf{7}$ with TFA/diethyl ether afforded the [Val-Pro]-[Val]-[acetaminophen] conjugate 8 as its trifluoroacetate salt in $98 \%$ yield.
We next synthesized the tripeptide prodrug derivative of propranolol 12 (Scheme 4). Coupling of the commercially available racemic propranolol hydrochloride with $\mathrm{Fmoc}-\mathrm{Val}-\mathrm{OH}$ in

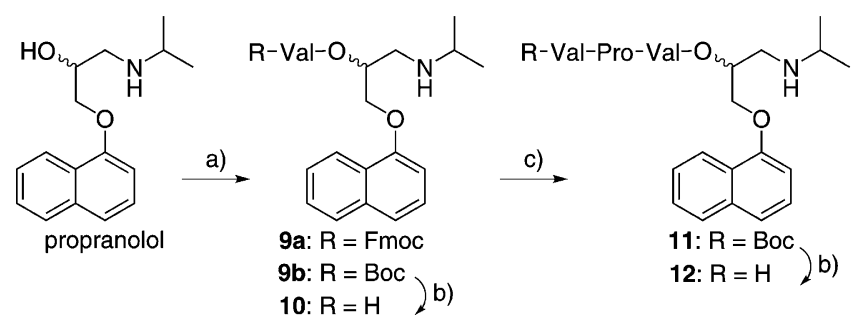

Scheme 4. Synthesis of [Val-Pro]-[Val]-[propranolol] conjugate 12. Reagents and conditions: a) Fmoc-Val-OH or Boc-Val-OH, BOP, TEA, $\mathrm{CH}_{2} \mathrm{Cl}_{2}, 15 \mathrm{~h}, \mathrm{RT}$; b) $\mathrm{HCl}$ in EtOAc, $3 \mathrm{~h}, \mathrm{RT}$; c) Boc-Val-Pro-OH, BOP, TEA, $\mathrm{CH}_{2} \mathrm{Cl}_{2}, 15 \mathrm{~h}, \mathrm{RT}$.

the presence of $B O P / T E A / \mathrm{CH}_{2} \mathrm{Cl}_{2}$ yielded the Fmoc-valyl intermediate $9 \mathrm{a}$ in good yield $(81 \%)$ as a diastereomeric mixture. Surprisingly, this $\mathrm{N}$-protected compound proved to be chemically unstable, degrading over time into a mixture of prodrugs in which propranolol was detected as the major compound. The observed instability was greater for the corresponding unprotected derivative 10. Thus, 10 was never detected after basic treatment of $9 \mathrm{a}$ ( $5 \%$ piperidine in DMF), and only propranolol was obtained. ${ }^{[24]}$ To get a more stable valyl intermediate, we decided to change to a Boc-protected strategy. Acylation of propranolol with Boc-Val-OH under standard coupling conditions gave compound $\mathbf{9 b}$ ( $71 \%$ yield), followed by Bocdeprotection in acidic media $(2 \mathrm{~N} \mathrm{HCl}$ in ethyl acetate) to afford the desired valyl derivative $\mathbf{1 0}$ as a dihydrochloride salt ( $95 \%$ yield). Coupling of 10 with Boc-Val-Pro-OH using BOP and TEA yielded the Boc-protected tripeptide derivative 11 in good yield (72\%). Acid-mediated deprotection of 11 provided the target prodrug 12 as a dihydrochloride salt in $95 \%$ yield (Scheme 4).

Finally, we carried out synthesis of the tripeptide prodrug of camptothecin 16 (Scheme 5). Acylation of the sterically hindered and deactivated tertiary hydroxy group of camptothecin with Boc-Val-OH was first attempted following the acylation procedure described above. However, treatment of camptothecin with Boc-Val-OH in the presence of DCC/DMAP or BOP/TEA failed to give the valyl intermediate 13 . This coupling reaction did not occur in the presence of other coupling reagents [(benzotriazol-1-yloxy)-tris-(pyrrolidino)phosphonium hexafluorophosphate, O-(7-azabenzotriazol-yl)tetramethyl uronium hexafluorophosphate, 1-[bis(dimethylamino)methylene]-5-chloro$1 \mathrm{H}$-benzotriazolium 3-oxide hexafluorophosphate, or bis(trichloromethyl)carbonate (commonly known as triphosgene)] under basic conditions at room temperature, at reflux, or by using microwave irradiation. We successfully obtained the Bocvalyl derivative 13 by using symmetric anhydride of the BocVal-OH with $N, N^{\prime}$-diisopropylcarbodiimide as a coupling reagent and a catalytic amount of DMAP as a base. ${ }^{[25]}$ Addition of a freshly prepared anhydride form of Boc- $\mathrm{Val}-\mathrm{OH}$ to a solution of camptothecin in $\mathrm{CH}_{2} \mathrm{Cl}_{2}$ under microwave irradiation at $80^{\circ} \mathrm{C}$ gave the desired compound 13 in $51 \%$ yield, although a 


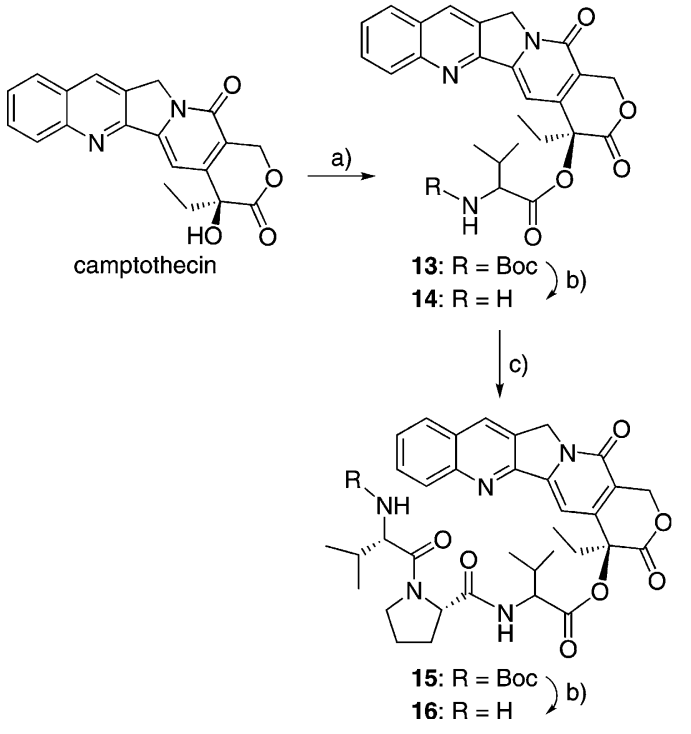

Scheme 5. Synthesis of the tripeptide prodrug of camptothecin 16. Reagents and conditions: a) Boc-Val-OH, N,N'-diisopropylcarbodiimide, DMAP, $\mathrm{CH}_{2} \mathrm{Cl}_{2}$ / DMF, 10 min at $0^{\circ} \mathrm{C}, 10 \mathrm{~min}$ at $\mathrm{RT}$, then $1 \mathrm{~h}$ at $80^{\circ} \mathrm{C}(\mathrm{MW})$; b) $\mathrm{HCl}$ in $\mathrm{CH}_{3} \mathrm{OH}$, 5 h, RT; c) Boc-Val-Pro-OH, BOP, TEA, $\mathrm{CH}_{2} \mathrm{Cl}_{2}, 15$ h, RT.

high extent of epimerization was observed during the coupling reaction and an epimeric ratio of 1:1 was determined by ${ }^{1} \mathrm{H}$ NMR. Epimerization has also been previously described in the acylation of the hydroxy group of camptothecin with bulky or $\beta$-branched N-protected amino acids. ${ }^{[26]}$ After deprotection of the epimeric mixture of Boc-derivative 13 in acidic media $(2 \mathrm{~N} \mathrm{HCl}$ in ethyl acetate), the resulting hydrochloride salt 14 was subjected to coupling with Boc-Val-Pro-OH under standard coupling conditions (BOP/TEA) to give the protected tripeptide 15 in $64 \%$ yield. Acid-mediated $\mathrm{N}$-deprotection of 15 resulted in the target [Val-Pro]-[Val]-[camptothecin] 16 as a hydrochloride salt in good yields. ${ }^{[27]}$

In addition, the water solubility of the [Val-Pro]-[Val]-[camptothecin] prodrug (16) was determined in phosphate-buffered saline (PBS) at various $\mathrm{pH}$ values and compared with that of the parent drug. As expected, increased solubility was obtained at lower $\mathrm{pH}$. The prodrug $\mathbf{1 6}$ had an aqueous solubility ranging from $1.21 \mathrm{mg} \mathrm{mL}^{-1}(\mathrm{pH} 7.4)$ to $15.40 \mathrm{mg} \mathrm{mL}^{-1}(\mathrm{pH} 5.0)$, representing a 60 to 205 -fold increase over the poorly soluble parent compound $\left(0.02 \mathrm{mg} \mathrm{mL}^{-1}\right.$ and $0.075 \mathrm{mg} \mathrm{mL}^{-1}$ at $\mathrm{pH} 7.4$ and 5.0, respectively). This result supports a general applicability of the DPPIV/CD26 prodrug approach for increasing the water solubility of hydrophobic drugs.

\section{Biological studies}

The stability of didanosine, [Val]-[didanosine] (2) and [Val-Pro][Val]-[didanosine] (4) was first examined in PBS (pH 7.6). Whereas didanosine (data not shown) and the tripeptide of didanosine (Figure $4 \mathrm{~B}$, panel a) were fully stable for up to $24 \mathrm{~h}$, the [Val]-[didanosine] prodrug slowly converted into its parental didanosine ( $50 \%$ conversion after $24 \mathrm{~h}$; Figure $4 \mathrm{~A}$, panel a). As expected, DPPIV/CD26 had no effect on the conversion of 2 to didanosine (Figure 4A, panel b). Human (HS; Figure 4A, panel c) and bovine (BS; data not shown) serum, in addition to enabling spontaneous release of the valyl moiety from 2, partially converted 2 to didanosine. However, when [Val-Pro]-[Val][didanosine] derivative $\mathbf{4}$ was exposed to DPPIV/CD26, virtually all prodrug was converted into 2 and didanosine within 60 min (Figure 4B, panel b). Additionally, HS and BS released 2 and didanosine from 4 in a time-dependent manner (data not shown). After $24 \mathrm{~h}$ incubation, $90 \%$ or more of the tripeptide prodrug $\mathbf{4}$ was converted into [Val]-[didanosine] 2 and didanosine (Figure 4B, panel c). Stability data of $\mathbf{2}$ and $\mathbf{4}$ in BS (data not shown) were fairly similar to that obtained in HS. Thus, we concluded that DPPIV/CD26, as well as HS and BS, efficiently release the [Val-Pro] moiety from the tripeptide [Val-Pro]-[Val][didanosine].

The [Val-Pro]-[Val] prodrug 8 of acetaminophen was more stable in PBS than [Val]-[acetaminophen] prodrug 6 (compare Figure $5 \mathrm{~A}$, panel a and Figure $5 \mathrm{~B}$, panel a). Whereas $80 \%$ of intact prodrug 8 was recovered after $24 \mathrm{~h}, \sim 50 \%$ of [Val]-[acetaminophen] prodrug 6 was converted within $4 \mathrm{~h}$ to acetaminophen. This higher stability of the tripeptide versus the valyl derivative of acetaminophen was also observed for the [Val-Pro][Val] and [Val]-[didanosine] prodrugs (Figure 4A, B). Conversion of the valyl derivative of acetaminophen to parent acetaminophen occurred more quickly in the presence of DPPIV/CD26 and particularly in the presence of HS (Figure $5 \mathrm{~A}$, panels $\mathrm{b}$ and c) and BS (data not shown). The exposure of 8 to DPPIV/CD26 led to virtually $100 \%$ conversion of 8 to acetaminophen within 60 min (Figure 5B, panel b). Serum, particularly HS (BS; data not shown), also efficiently converted the tripeptide of paracetaminophen to the parent compound. Because the tripeptidyl [Val-Pro]-[Val] derivative of acetaminophen could not be efficiently separated from [Val]-[acetaminophen], it is unclear whether acetaminophen can be directly derived from the tripeptidyl prodrug $\mathbf{8}$, or, more likely, whether $\mathbf{8}$ must be converted into valyl derivative 6 prior to the formation of acetaminophen.

The [Val] (10) and [Val-Pro]-[Val] (12) derivatives of propranolol were very chemically instable (Figure $6 \mathrm{~A}$ and $\mathrm{B}$, panels a). When introduced into PBS solution, $40 \%$ to $90 \%$ of the prodrugs converted into propranolol within $15 \mathrm{~min}$. Chemical instability of propranolol prodrugs could be explained by intramolecular base catalysis of the unprotonated amino group via attack by a water molecule. ${ }^{[28]}$ In an attempt to examine the effect of DPPIV/CD26 on the prodrug solution, fresh solutions of both propranolol prodrugs were exposed to DPPIV/CD26 and analyzed as a function of incubation time (Figure $6 \mathrm{~A}$ and $B$, panels b). In both cases, DPPIV/CD26 exposure appeared to induce slightly quicker conversion of the prodrugs to the parent compound, suggesting a marginally increased conversion rate in the DPPIV/CD26 assay in addition to spontaneous conversion of the prodrugs due to their chemical instability. It is currently unclear whether this enzymatic reaction is physiologically relevant. It should also be mentioned that both prodrug preparations consisted of two peaks on the HPLC chromatograms with very close retention times, indicating the presence (and separation) of both diastereomers $\left[t_{\mathrm{R}}\right.$ (retention time) 26.9 and $27.0 \mathrm{~min}$ for 10 and 28.8 and $29.2 \mathrm{~min}$ for 12]. 
A)

a) PBS

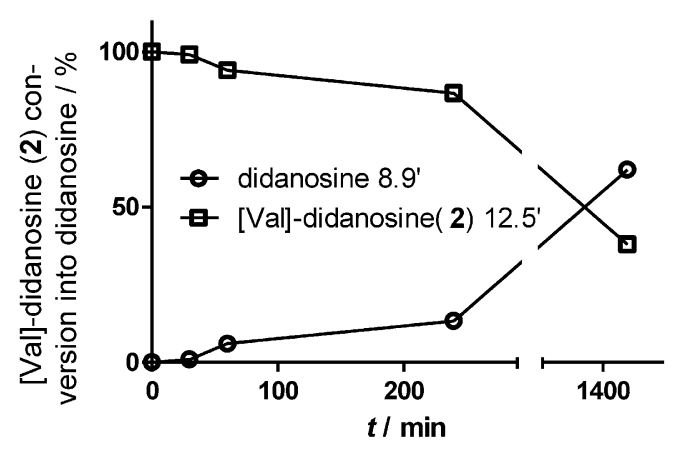

b) $\mathrm{CD} 26$

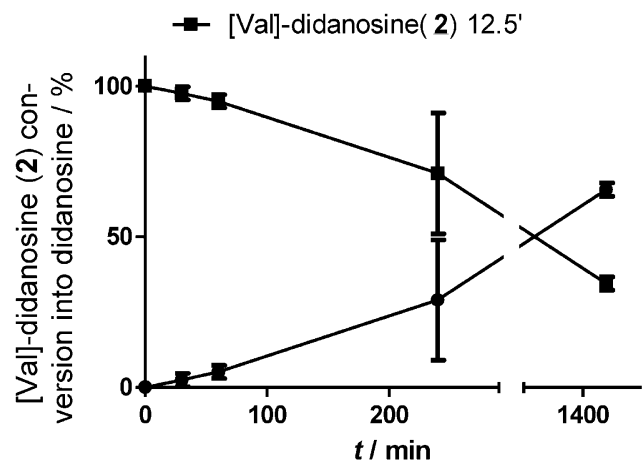

c) $\mathrm{HS}$

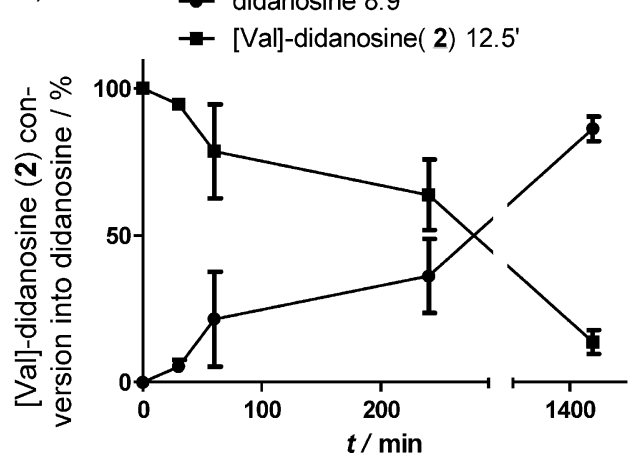

B)
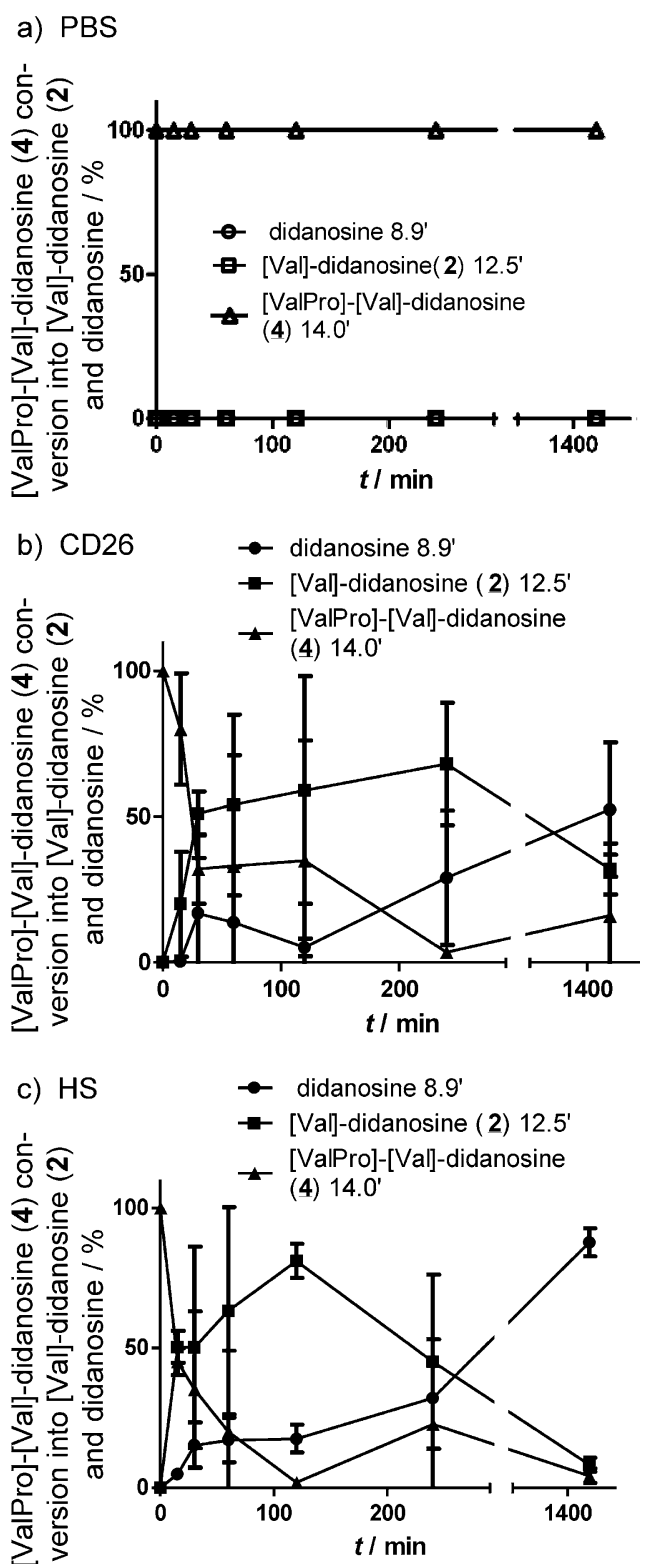

Figure 4. A) Chemical stability of [Val]-[didanosine] prodrug 2 in PBS (panel a, open symbols), and conversion of [Val]-[didanosine] prodrug 2 to parent compound in the presence of DPPIV/CD26 (panel b) and $20 \%$ human serum (panel $c$ ). The retention times $\left(t_{R}\right)$ in min are given for each metabolite. The nature of each metabolite is indicated between parentheses; B) Chemical stability of [Val-Pro]-[Val]-[didanosine] prodrug 4 in PBS (panel a, open symbols), and conversion of [Val-Pro]-[Val]-[didanosine] prodrug 4 to parent compound in the presence of DPPIV/CD26 (panel b) and $20 \%$ human serum (panel c). The retention times $\left(t_{\mathrm{R}}\right)$ in $\mathrm{min}$ are given for each metabolite. The nature of each metabolite is indicated between parentheses.

Analysis of the conversion of the [Val-Pro]-[Val]-[propranolol] to propranolol over brief time periods $(5,10$, and $15 \mathrm{~min}$ ) revealed that the peak fraction with the earliest retention time disappeared more quickly than the peak fraction with the longer retention time (data not shown).

Finally, the [Val] (14) and [Val-Pro]-]Val] (16) prodrugs of camptothecin were investigated. The parent compound, as well as both prodrugs, were fairly chemically stable in PBS. Prodrug 14 was $80 \%$ intact after $2 \mathrm{~h}$ (Figure $7 \mathrm{~A}$, panel a), whereas prodrug 16 was more than $90 \%$ intact after $2 \mathrm{~h}$ in PBS (Figure $7 \mathrm{~B}$, panel a). With the exception of its spontaneous degradation, 14 proved reasonably stable for up to $2 \mathrm{~h}$ in the pres- ence of DPPIV/CD26 and HS. However, after $24 \mathrm{~h}$, significant appearance of metabolites with $t_{R}$ values of 16.5 and $16.9 \mathrm{~min}$ were observed. In HS, formation of a metabolite with a $t_{\mathrm{R}}$ of 15.7 min was prominent, and emerged as the major species in the reaction mixture at $2 \mathrm{~h}$ and $24 \mathrm{~h}$. This metabolite was not observed in the other tests (DPPIV/CD26 and BS; data not shown), and its identity is unknown. The tripeptide prodrug 16, which is highly stable in PBS, was converted into 14 and into parent drug and metabolite $16.5^{\prime}$ in the presence of DPPIV/CD26 in a time-dependent manner. Interestingly, both HS and BS hydrolyzed 16 (BS data not shown) in a time-dependent manner but, as also observed in HS-exposed [Val]-camp- 
A)

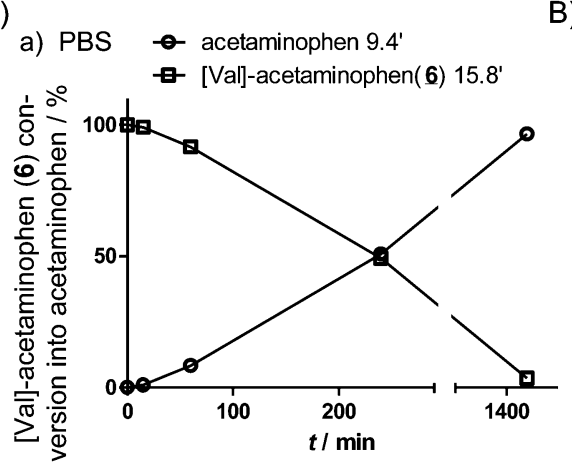

b) $\begin{array}{ll}\text { CD26 } & \rightarrow-\text { acetaminophen } 9.4^{\prime} \\ & \rightarrow[\text { [Val]-acetaminophen(6) 15.8' }\end{array}$

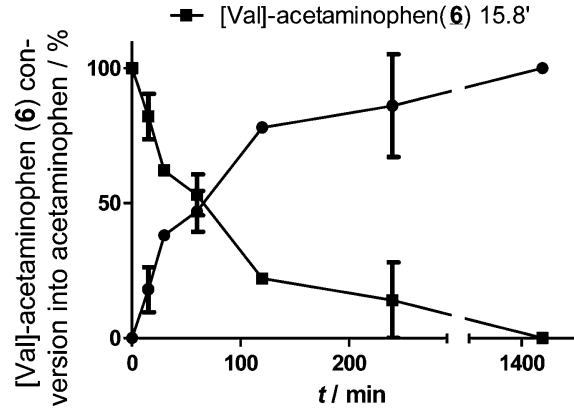

c) HS

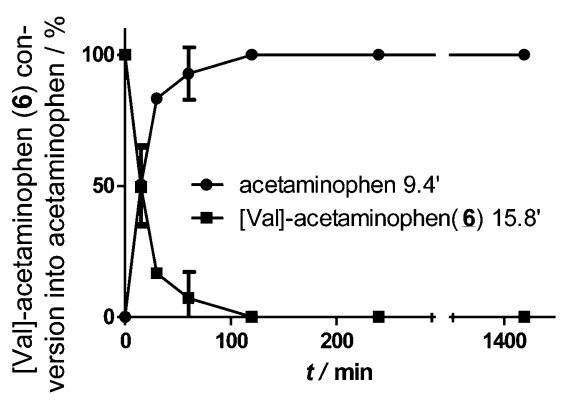

B)

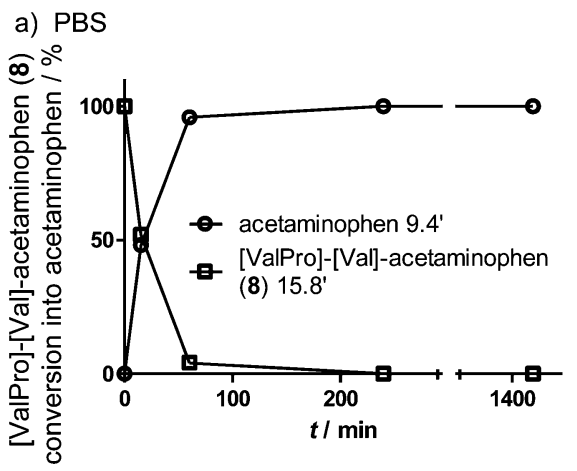

b) $\mathrm{CD} 26$

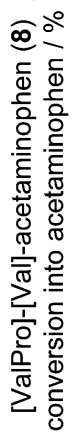

c) $\mathrm{HS}$

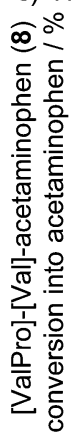

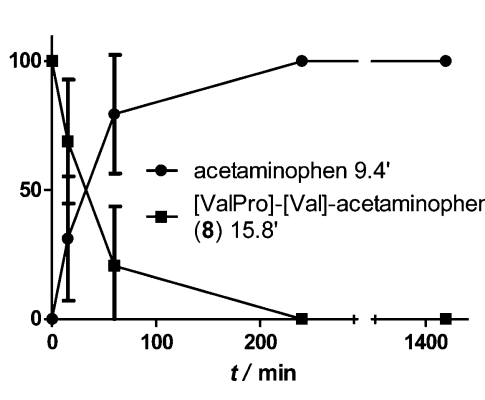

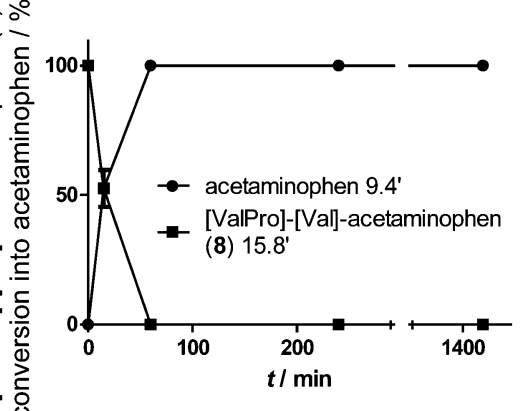

Figure 5. A) Chemical stability of [Val]-[acetaminophen] prodrug 6 in PBS (panel a, open symbols), and conversion of [Val]-[acetaminophen] prodrug 6 to parent compound in the presence of DPPIV/CD26 (panel b) and 20\% human serum (panel c). The retention times $\left(t_{R}\right)$ in min are given for each metabolite. The nature of each metabolite is indicated between parentheses; B) Chemical stability of [Val-Pro]-[Val]-[acetaminophen] prodrug 8 in PBS (panel a, open symbols), and conversion of [Val-Pro]-[Val]-[acetaminophen] prodrug 8 to parent compound in the presence of DPPIV/CD26 (panel b) and $20 \%$ human serum (panel c). The retention times $\left(t_{R}\right)$ in min are given for each metabolite. The nature of each metabolite is indicated between parentheses.

the tripeptide prodrug derivative may not only have the advantage of increased solubility and better formulation but may also result in an increased oral bioavailability, as previously demonstrated for the tripeptidyl (ValPro-Val) derivatives of bicyclic nucleoside analogue $\mathrm{Cf} 1743$. $^{[20]}$

\section{Conclusions}

In conclusion, DPPIV/CD26 was able to hydrolyze tripeptide prodrugs of hydroxy-containing compounds, irrespective of the nature of the $\mathrm{OH}$ group. However, the susceptibility of the various prodrugs to conversion by DPPIV/CD26 or serum was highly dependent on the nature of the parent drug and/or the property of the free hydroxy moiety. In general, the [Val-Pro]-[Val] tripeptide derivatives showed pronounced compound stability in PBS in contrast with the corresponding valyl derivatives, which were often spontaneously converted into the parent drug and/ or to yet uncharacterized metabolite(s). Our findings show that moderately stable tripeptide prodrugs can be prepared from lipophilic drugs bearing a free hydroxy group. Such prodrugs may markedly increase the solubility of the parent drugs, giving these prodrugs a therapeutic edge over their lipophilic and primarily insoluble parent compounds. tothecin, only $\mathrm{HS}$ resulted in the formation of a metabolite with a $t_{\mathrm{R}}$ of 15.7 min (Figure 7B, panel $\mathrm{C}$ ).

The gastrointestinal tract contains high levels of CD26 in the intestinal cells. ${ }^{[29]}$ As a result, a quantity of the peptide prodrugs will be cleaved in the gastrointestinal environment, releasing the dipeptide prodrug moiety. In the case of the tripeptide prodrugs, following cleavage to the valine derivative, the intestinal hPEPT-1 transporter may recognize and take up the cleaved prodrug and uncleaved tripeptides containing a terminal valyl moiety on the apical side, releasing the parent compound on the basolateral side to enter systemic circulation. ${ }^{[30]}$ This may result in an increased oral bioavailability of the prodrug relative to the parent drug and the valyl prodrug. Thus,

\section{Experimental Section}

\section{Chemical procedures}

General: Microanalyses were obtained using a Heraeus CHN-ORapid instrument. Electrospray mass spectra were measured on a quadrupole mass spectrometer equipped with an electrospray source (Hewlett-Packard, LC/MS HP 1100). Spectra were recorded with Varian Inova-300 or Varian Inova-400 spectrometers operating at 300 or $400 \mathrm{MHz}$ for ${ }^{1} \mathrm{H}$ NMR and at 75 or $100 \mathrm{MHz}$ for ${ }^{13} \mathrm{C}$ NMR with trimethylsilane as an internal standard. Analytical thin-layer chromatography (TLC) was performed on silica gel $60 \mathrm{~F}_{254}$ (Merck). Separations were performed by flash column chromatography with silica gel 60 (230-400 mesh; Merck) or preparative centrifugal circular thin layer chromatography (CCTLC) on a Chromatotron Kiesel- 
A)

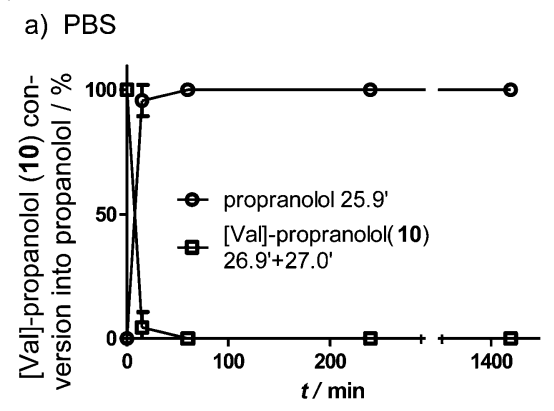

b) CD26

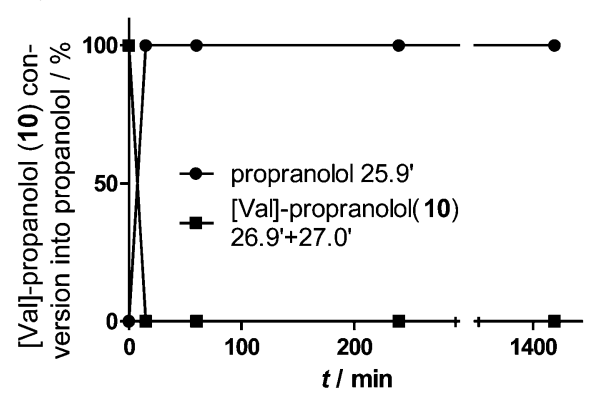

B)

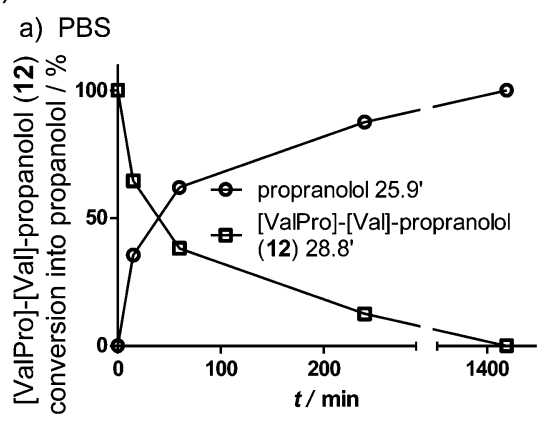

b) $\mathrm{CD} 26$

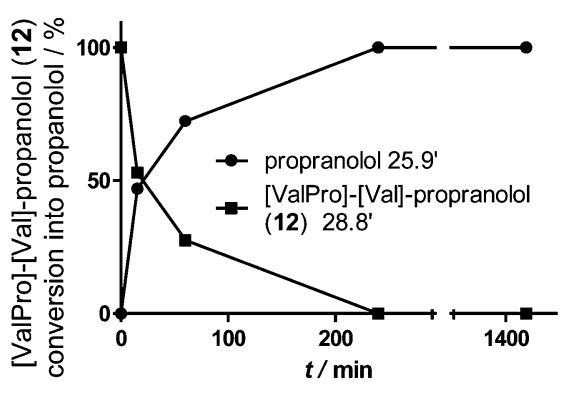

Figure 6. A) Chemical stability of [Val]-[propranolol] prodrug 10 in PBS (panel a, open symbols), and conversion of [Val]-[propranolol] prodrug 10 to parent compound in the presence of DPPIV/CD26 (panel b); B) Chemical stability of [Val-Pro]-[Val]-[propranolol] prodrug 12 in PBS (panel a, open symbols), and conversion of [Val-Pro]-[Val]-[propranolol] prodrug 12 to parent compound in the presence of DPPIV/CD26 (panel b). The retention times $\left(t_{R}\right)$ in min are indicated for the respective metabolites. The nature of each metabolite, if known, is indicated between parentheses.

gel $60 \mathrm{PF}_{254}$ gipshaltig (silica gel containing gypsum; Merck), $1 \mathrm{~mm}$

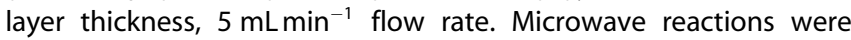
performed using the Biotage Initiator 2.0 single-mode cavity instrument. Experiments were carried out in sealed microwave process vials using the standard absorbance level ( $400 \mathrm{~W}$ maximum power). The temperature was measured with an IR sensor on the outside of the reaction vessel. Dipeptide derivatives Fmoc-Val-Pro$\mathrm{OH}$ and Boc-Val-Pro-OH were purchased from Bachem. Other chemicals and suppliers were: acetaminophen (Fluka), rac-propranolol hydrochloride (Sigma-Aldrich), and camptothecin ( $\mathrm{TCl}$ Europe).

2', 3'-Dideoxy-5'-O-[N(fluorenylmethoxycarbonyl)valyl]inosine (1): DMAP (15 mg, $0.13 \mathrm{mmol})$, Fmoc-Val-OH (288 mg, $0.85 \mathrm{mmol})$, and DCC (175 mg, $0.85 \mathrm{mmol})$ were added to a solution of didanosine $(100 \mathrm{mg}, 0.42 \mathrm{mmol})$ in DMF $(6 \mathrm{~mL})$ at $0^{\circ} \mathrm{C}$. The reaction mixture was stirred at RT for $4 \mathrm{~h}$. The resulting white solid was filtered and washed with DMF, and the solvent was eliminated in vacuo. The residue was dissolved in EtOAc $(30 \mathrm{~mL})$ and washed with $10 \%$ aqueous citric acid $(3 \times 20 \mathrm{~mL}), 10 \%$ aqueous $\mathrm{NaHCO}_{3}(3 \times 20 \mathrm{~mL})$, $\mathrm{H}_{2} \mathrm{O}(3 \times 20 \mathrm{~mL})$, and brine $(3 \times 20 \mathrm{~mL})$. The organic layer was dried $\left(\mathrm{Na}_{2} \mathrm{SO}_{4}\right)$, filtered, and evaporated to dryness. The final residue was purified by flash chromatography $\left(\mathrm{CH}_{2} \mathrm{Cl}_{2} / \mathrm{CH}_{3} \mathrm{OH}, 15: 1\right)$ to afford 1 as a white foam (223 mg, $94 \%$ yield): ${ }^{1} \mathrm{H}$ NMR $(300 \mathrm{MHz}$, $\left[\mathrm{D}_{6}\right.$ ]acetone): $\delta=0.94-0.98(\mathrm{~m}, 6 \mathrm{H}), 2.11-2.29(\mathrm{~m}, 3 \mathrm{H}), 2.54-2.61$ $(\mathrm{m}, 2 \mathrm{H}), 4.15-4.45(\mathrm{~m}, 7 \mathrm{H}), 6.28(\mathrm{t}, J=5.4 \mathrm{~Hz}, 1 \mathrm{H}), 6.84(\mathrm{~d}, J=$ $8.5 \mathrm{~Hz}, 1 \mathrm{H}), 7.32(\mathrm{~m}, 2 \mathrm{H}), 7.41(\mathrm{~m}, 2 \mathrm{H}), 7.70(\mathrm{t}, J=8.0 \mathrm{~Hz}, 2 \mathrm{H}), 7.83$ (d, $J=7.5 \mathrm{~Hz}, 2 \mathrm{H}), 8.11(\mathrm{~s}, 1 \mathrm{H}), 8.15(\mathrm{~s}, 1 \mathrm{H}), 11.33 \mathrm{ppm}(\mathrm{bs}, 1 \mathrm{H})$; ${ }^{13} \mathrm{C} \mathrm{NMR}(75 \mathrm{MHz}$, [D 6 ]acetone): $\delta=18.8,19.9,27.5,31.7,33.2,48.4$, $61.1,67.2,67.7,80.0,86.6,121.2,125.0,126.6,128.3,129.6,136.3$, 139.3, 142.5, 146.4, 157.7, 172.9 ppm; MS $\left(\mathrm{ESI}^{+}\right): \mathrm{m} / \mathrm{z} 558.3[\mathrm{M}+$
$\mathrm{H}]^{+}, 580.3[\mathrm{M}+\mathrm{Na}]^{+}, 1115.5[2 \mathrm{M}+$ $\mathrm{H}^{+}$; anal. calcd for $\mathrm{C}_{30} \mathrm{H}_{31} \mathrm{~N}_{5} \mathrm{O}_{6}: \mathrm{C}$ $64.62, \mathrm{H}$ 5.60, N 12.56; found: C 64.79, H $5.56, \mathrm{~N} 12.60$.

\section{2',3'-Dideoxy-5'-O-valylinosine}

(2): ${ }^{[31]} \quad$ Piperidine $\quad(0.25 \mathrm{~mL}$, $2.5 \mathrm{mmol}$ ) was added to a solution of 1 ( $275 \mathrm{mg}, 0.49 \mathrm{mmol})$ in DMF $(5 \mathrm{~mL})$. The reaction mixture was stirred at RT for $5 \mathrm{~min}$, then the solvent was evaporated to dryness. The final residue was purified by CCTLC using the Chromatotron $\left(\mathrm{CH}_{2} \mathrm{Cl}_{2} / \mathrm{CH}_{3} \mathrm{OH}, 15: 1\right)$ to give 2 as a yellow foam (132 $\mathrm{mg}, 80 \%$ yield): ${ }^{1} \mathrm{H} N M R \quad\left(300 \mathrm{MHz}, \quad\left[\mathrm{D}_{6}\right]\right.$ acetone): $\delta=0.88(\mathrm{~d}, J=6.8 \mathrm{~Hz}, 3 \mathrm{H}), 0.90(\mathrm{~d}$, $J=6.8 \mathrm{~Hz}, 3 \mathrm{H}), 2.17-2.29(\mathrm{~m}, 3 \mathrm{H})$, 2.56-2.63 $(\mathrm{m}, 2 \mathrm{H}), 3.88(\mathrm{~d}, J=$ $6.8 \mathrm{~Hz}, 1 \mathrm{H}), 4.25-4.46(\mathrm{~m}, 3 \mathrm{H}), 6.32$ $(\mathrm{t}, J=5.9 \mathrm{~Hz}, 1 \mathrm{H}), 8.13(\mathrm{~s}, 1 \mathrm{H}), 8.33$ $(\mathrm{s}, 1 \mathrm{H}), 11.33 \mathrm{ppm}$ (bs, 1H); MS $\left(\mathrm{ESI}^{+}\right): \mathrm{m} / \mathrm{z}$ 336.2, $[\mathrm{M}+\mathrm{H}]^{+}, 358.3$ $[2 \mathrm{M}+\mathrm{H}]^{+}$.

\section{2',3'-Dideoxy-5'-O-[N-(fluorenyl-} methoxycarbonyl)valylprolylvalyI]inosine (3): Fmoc-Val-Pro-OH (183 mg, $0.42 \mathrm{mmol}$ ), BOP (185 mg, $0.42 \mathrm{mmol})$, and TEA $(0.06 \mathrm{~mL}$, $0.42 \mathrm{mmol}$ ) were added to a solution of $2(170 \mathrm{mg}, 0.35 \mathrm{mmol})$ in $\mathrm{CH}_{2} \mathrm{Cl}_{2}(5 \mathrm{~mL})$. The reaction mixture was stirred at RT for $15 \mathrm{~h}$, then the solvent was evaporated to dryness. The residue was dissolved in EtOAc $(50 \mathrm{~mL})$ and washed with $10 \%$ aqueous citric acid $(3 \times 20 \mathrm{~mL}), 10 \%$ aqueous $\mathrm{NaHCO}_{3}(3 \times$ $20 \mathrm{~mL}), \mathrm{H}_{2} \mathrm{O}(3 \times 20 \mathrm{~mL})$, and brine $(3 \times 20 \mathrm{~mL})$. The organic layer was dried $\left(\mathrm{Na}_{2} \mathrm{SO}_{4}\right)$, filtered, and evaporated to dryness. The final residue was purified by flash chromatography $\left(\mathrm{CH}_{2} \mathrm{Cl}_{2} / \mathrm{CH}_{3} \mathrm{OH}, 15: 1\right)$ to give 3 as a white foam (190 mg, 73\% yield): ${ }^{1} \mathrm{H}$ NMR $(300 \mathrm{MHz}$, $\left[\mathrm{D}_{6}\right]$ acetone): $\delta=0.89-1.02(\mathrm{~m}, 12 \mathrm{H}), 2.07-2.41(\mathrm{~m}, 8 \mathrm{H}), 2.57-2.64$ $(\mathrm{m}, 2 \mathrm{H}), 3.67-3.82(\mathrm{~m}, 2 \mathrm{H}), 4.21-4.60(\mathrm{~m}, 9 \mathrm{H}), 6.30(\mathrm{t}, J=5.5 \mathrm{~Hz}$, $1 \mathrm{H}), 6.65(\mathrm{~d}, J=9.0 \mathrm{~Hz}, 1 \mathrm{H}), 7.31(\mathrm{~m}, 2 \mathrm{H}), 7.39(\mathrm{t}, J=7.5 \mathrm{~Hz}, 2 \mathrm{H})$, $7.65(\mathrm{~d}, J=7.9 \mathrm{~Hz}, 1 \mathrm{H}), 7.70(\mathrm{t}, J=8.0 \mathrm{~Hz}, 2 \mathrm{H}), 7.84(\mathrm{~d}, J=7.5 \mathrm{~Hz}$, $2 \mathrm{H}), 8.12(\mathrm{~s}, 1 \mathrm{H}), 8.18(\mathrm{~s}, 1 \mathrm{H}), 11.33 \mathrm{ppm}(\mathrm{bs}, 1 \mathrm{H}) ; \mathrm{MS}\left(\mathrm{ESI}^{+}\right): \mathrm{m} / \mathrm{z}$ $754.3[\mathrm{M}+\mathrm{H}]^{+}, 776.3[\mathrm{M}+\mathrm{Na}]^{+}, 1507.6[2 \mathrm{M}+\mathrm{H}]^{+}$; anal. calcd for $\mathrm{C}_{40} \mathrm{H}_{47} \mathrm{~N}_{7} \mathrm{O}_{8}$ : C 63.73, H 6.28, N 13.01; found: C 63.94, H 6.31, N 13.05 .

2',3'-Dideoxy-5'-O-(valylprolylvalyl)inosine (4): According to the deprotection procedure described for compound 2, a solution of 3 $(170 \mathrm{mg}, 0.23 \mathrm{mmol})$ in DMF $(4 \mathrm{~mL})$ was treated with piperidine $(0.25 \mathrm{~mL}, 2.5 \mathrm{mmol})$. The final residue was purified by CCTLC using the Chromatotron (EtOAc/ $\left.\mathrm{CH}_{3} \mathrm{OH}, 5: 1\right)$ to give 4 as a yellow foam (110 mg, $91 \%$ yield): ${ }^{1} \mathrm{H}$ NMR (300 MHz, [ $\mathrm{D}_{6}$ ] acetone): $\delta=0.72-1.00$ $(\mathrm{m}, 12 \mathrm{H}), 1.84-2.30(\mathrm{~m}, 8 \mathrm{H}), 2.58-2.64\left(\mathrm{~m}, 2 \mathrm{H}, 2 \mathrm{H}-2^{\prime}\right), 3.46-3.81(\mathrm{~m}$, $2 \mathrm{H}), 3.97(\mathrm{~d}, J=8.4 \mathrm{~Hz}, 1 \mathrm{H}), 4.31-4.63(\mathrm{~m}, 5 \mathrm{H}), 6.29(\mathrm{t}, J=5.1 \mathrm{~Hz}$, $1 \mathrm{H}), 8.15(\mathrm{~s}, 1 \mathrm{H}), 8.17(\mathrm{~s}, 1 \mathrm{H}), 11.33 \mathrm{ppm}(\mathrm{bs}, 1 \mathrm{H}) ;{ }^{13} \mathrm{C} \mathrm{NMR}$ (75 MHz, [D $\mathrm{D}_{6}$ DMSO): $\delta=17.2,18.0,18.8,19.6,24.3,26.1,28.6,29.9$, $31.0,31.5,46.6,57.1,57.4,58.6,65.9,78.0,84.4,124.4,138.1,145.8$, 147.7, 156.7, 171.2, 171.9, 173.6 ppm; MS (ESI+): $\mathrm{m} / \mathrm{z} 532.1[\mathrm{M}+$ $\mathrm{H}]^{+}, 1063.2[2 \mathrm{M}+\mathrm{H}]^{+}$; anal. calcd for $\mathrm{C}_{25} \mathrm{H}_{37} \mathrm{~N}_{7} \mathrm{O}_{6}$ : C 56.48, $\mathrm{H}$ 7.02, N 18.44; found: C 56.66, H 6.99, N 18.56. 
A)

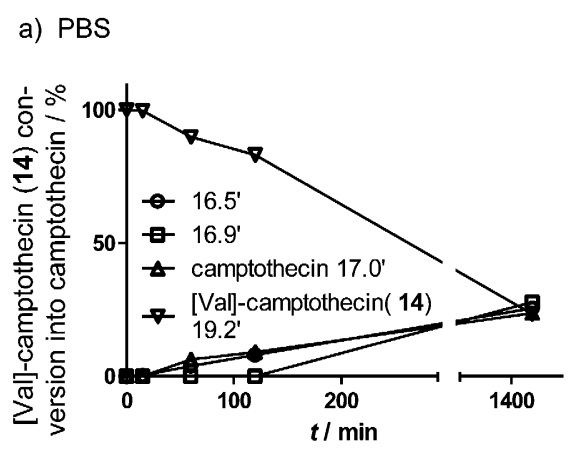

b) $\operatorname{CD} 26$

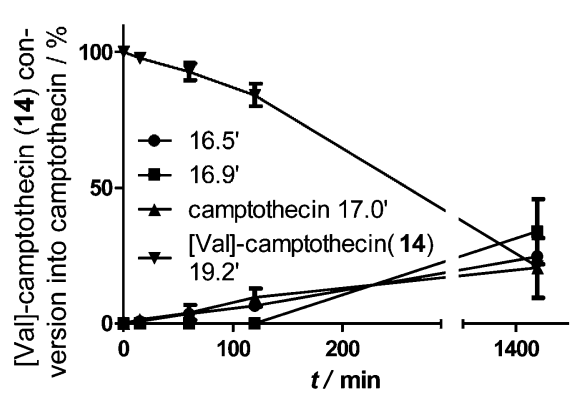

$\begin{aligned} & \rightarrow 15.1^{\prime} \rightarrow \text { camptothecin } 17.0^{\prime} \\ \text { c) HS } & \rightarrow 15.7^{\prime} \rightarrow \text { [Vall-camptothecin( 14) } \\ & \neq 16.5^{\prime} \rightarrow 19.2^{\prime}\end{aligned}$

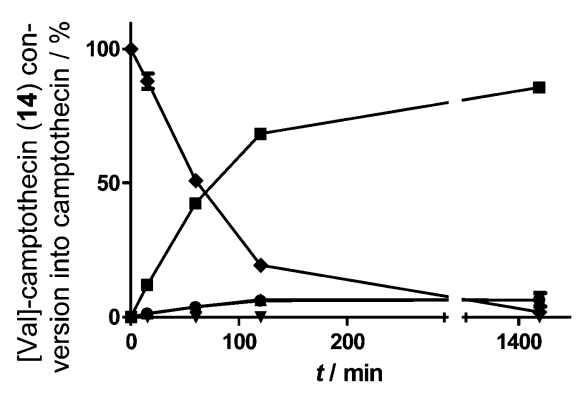

B)

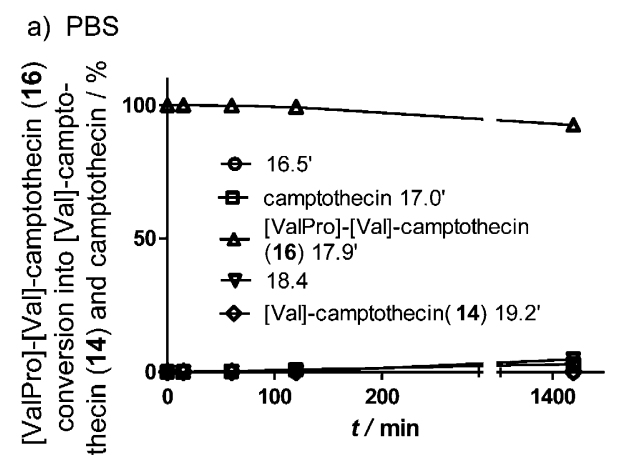

b) $\mathrm{CD} 26$

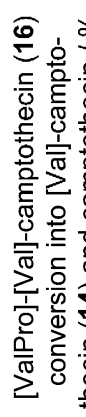

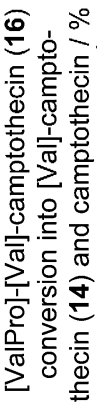

$\rightarrow 16.5^{\prime}$

- camptothecin 17.0

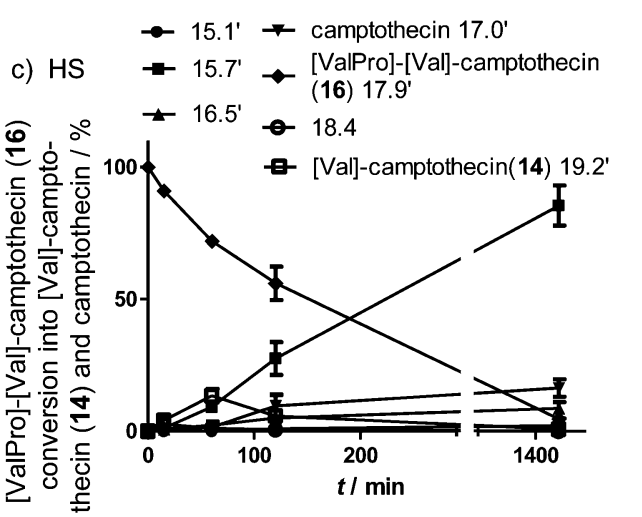

Figure 7. A) Chemical stability of [Val]-[camptothecin] prodrug 14 in PBS (panel a, open symbols), and conversion of [Val]-[camptothecin] prodrug 14 to parent compound in the presence of DPPIV/CD26 (panel b) and 20\% human serum (panel c). Retention times $\left(t_{R}\right)$ in min are indicated for the respective metabolites. The nature of each metabolite, if known, is indicated between parentheses; B) Chemical stability of [Val-Pro]-[Val]-[camptothecin] prodrug 16 in PBS (panel a, open symbols), and conversion of [Val-Pro]-[Val]-[camptothecin] prodrug 16 to parent compound in the presence of DPPIV/CD26 (panel b) and $20 \%$ human serum (panel c). The designation of metabolites that emerged for which no firm identification was possible are indicated by their retention times $\left(t_{\mathrm{R}}\right)$.

O-[N-(9-Fluorenylmethoxycarbonyl)valyl]acetaminophen

(5a): Following a coupling procedure similar to that described for compound 1, DMAP $(0.061 \mathrm{~g}, 0.49 \mathrm{mmol})$, Fmoc-Val-OH $(1.12 \mathrm{~g}$, $3.31 \mathrm{mmol})$, and DCC $(0.682 \mathrm{~g}, 3.31 \mathrm{mmol})$ were added to a solution of acetaminophen $(0.250 \mathrm{~g}, 1.65 \mathrm{mmol})$ in DMF $(5 \mathrm{~mL})$ at $0{ }^{\circ} \mathrm{C}$. The reaction mixture was stirred at $\mathrm{RT}$ for $2 \mathrm{~h}$. The final residue was purified by flash chromatography $\left(\mathrm{CH}_{2} \mathrm{Cl}_{2} / \mathrm{CH}_{3} \mathrm{OH}, 60: 1\right)$ to give $5 \mathrm{a}$ as a white foam $(0.659 \mathrm{~g}, 84 \%$ yield): 'H NMR $(300 \mathrm{MHz}$, $\left[\mathrm{D}_{6}\right.$ ] acetone): $\delta=1.09(\mathrm{~m}, 6 \mathrm{H}), 2.02(\mathrm{~s}, 3 \mathrm{H}), 2.29-2.37(\mathrm{~m}, 1 \mathrm{H}), 4.25$ $(\mathrm{m}, 1 \mathrm{H}), 4.34-4.40(\mathrm{~m}, 3 \mathrm{H}), 6.98-7.04(\mathrm{~m}, 3 \mathrm{H}), 7.28(\mathrm{~m}, 2 \mathrm{H}), 7.40(\mathrm{t}$, $J=7.2 \mathrm{~Hz}, 2 \mathrm{H}), 7.65-7.73(\mathrm{~m}, 4 \mathrm{H}), 7.85(\mathrm{~d}, J=7.5 \mathrm{~Hz}, 2 \mathrm{H}), 9.24 \mathrm{ppm}$ $(\mathrm{s}, 1 \mathrm{H}) ; \mathrm{MS}\left(\mathrm{ESI}^{+}\right): \mathrm{m} / \mathrm{z} 473.1[\mathrm{M}+\mathrm{H}]^{+}, 495.1[\mathrm{M}+\mathrm{Na}]^{+}, 945.5$ $[2 \mathrm{M}+\mathrm{H}]^{+}$; anal. calcd for $\mathrm{C}_{28} \mathrm{H}_{28} \mathrm{~N}_{2} \mathrm{O}_{5}: \mathrm{C}$ 71.17, $\mathrm{H}$ 5.97, N 5.93; found: C 71.27, H 6.00, N 5.95.
O-[N-(tert-Butoxycarbonyl)valyl]acetaminophen $(5 \mathrm{~b})$ : According to the procedure described for compound $1 \mathrm{a}$, a solution of acetaminophen (300 mg, $1.98 \mathrm{mmol})$ in DMF $(5 \mathrm{~mL})$ was combined with Boc-Val-OH (862 mg, $3.97 \mathrm{mmol})$ in the presence of DCC $(819 \mathrm{mg}$, $3.97 \mathrm{mmol}$ ) and DMAP (73 mg $0.59 \mathrm{mmol}$ ). The reaction mixture was stirred at RT for $2 \mathrm{~h}$. The final residue was purified by flash chromatography $\left(\mathrm{CH}_{2} \mathrm{Cl}_{2} / \mathrm{CH}_{3} \mathrm{OH}, 90: 1\right)$ to obtain $\mathbf{5 b}$ as a white foam (544 mg, $78 \%$ yield): $\quad{ }^{1} \mathrm{H} \mathrm{NMR}$ (300 MHz, $\quad\left[\mathrm{D}_{6}\right]$ acetone): $\delta=1.06$ $(\mathrm{m}, J=6.9 \mathrm{~Hz}, 3 \mathrm{H}), 1.09(\mathrm{~m}, J=$ $6.9 \mathrm{~Hz}, 3 \mathrm{H}), 1.42(\mathrm{~s}, 9 \mathrm{H}), 2.07(\mathrm{~s}$, $3 \mathrm{H}), 2.25-2.34(\mathrm{~m}, 1 \mathrm{H}), 4.25(\mathrm{~m}$, $1 \mathrm{H}), 6.37(\mathrm{~d}, J=7.5 \mathrm{~Hz}, 1 \mathrm{H}), 7.04$ and $7.67\left(\mathrm{AA}^{\prime} \mathrm{BB}^{\prime}\right.$ system, $J=8.8 \mathrm{~Hz}$, $4 \mathrm{H}), \quad 9.22 \mathrm{ppm}(\mathrm{s}, 1 \mathrm{H}) ;{ }^{13} \mathrm{C} \mathrm{NMR}$ (75 MHz, [D $]$ acetone): $\delta=19.5$, 20.5, 25.2, 29.5, 32.3, 61.4, 80.4, 121.6, 123.5, 139.2, 145.0, 153.8, 169.8, $172.8 \mathrm{ppm} ; \mathrm{MS}\left(\mathrm{ESI}^{+}\right): \mathrm{m} / \mathrm{z}$ $351.0[\mathrm{M}+\mathrm{H}]^{+}, 373.0[\mathrm{M}+\mathrm{Na}]^{+}$; anal. calcd for $\mathrm{C}_{18} \mathrm{H}_{26} \mathrm{~N}_{2} \mathrm{O}_{5}$ : C 61.70, H 7.48, N 7.99; found: C 61.45, H $7.52, \mathrm{~N} 8.02$.

O-Valylacetaminophen trifluoroacetate (6): ${ }^{[32]}$ TFA $(1.17 \mathrm{~mL}$, $15.3 \mathrm{mmol}$ ) was added to a solution of $1 \mathbf{b}(536 \mathrm{mg}, 1.53 \mathrm{mmol})$ in $\mathrm{Et}_{2} \mathrm{O}(8 \mathrm{~mL})$. The reaction mixture was stirred at RT for $7 \mathrm{~h}$, then the solvent was eliminated under reduced pressure. The residue was precipitated in EtOAc to obtain 6 as a white solid $(528 \mathrm{mg}, 95 \%$ yield): $\mathrm{mp}$ : $135-136^{\circ} \mathrm{C}$ (EtOAc); ${ }^{1} \mathrm{H}$ NMR (300 MHz, [D $]$ ]DMSO): $\delta=$ $1.08(\mathrm{~m}, 6 \mathrm{H}), 2.03(\mathrm{~s}, 3 \mathrm{H}), 2.25-$ $2.36(\mathrm{~m}, 1 \mathrm{H}), 4.18(\mathrm{~d}, J=5.8 \mathrm{~Hz}$, $1 \mathrm{H}), 7.09$ and 7.63 ( $\mathrm{AA}^{\prime} \mathrm{BB}^{\prime}$ system, $J=8.8 \mathrm{~Hz}, \quad 4 \mathrm{H}), \quad 8.43 \quad(\mathrm{bs}, \quad 3 \mathrm{H})$, $10.11 \mathrm{ppm} \quad(\mathrm{s}, \quad 1 \mathrm{H}) ; \quad{ }^{13} \mathrm{C}$ NMR (75 MHz, [D $\mathrm{D}_{6}$ DMSO): $\delta=17.6,18.2$, 23.8, 29.5, 57.3, 120.0, 121.5, 137.6, 144.6, 167.9, 168.3 ppm; MS $\left(\mathrm{ESI}^{+}\right): \mathrm{m} / \mathrm{z} 251.1[\mathrm{M}+\mathrm{H}]^{+}, 273.0[\mathrm{M}+\mathrm{Na}]^{+}, 501.2[2 \mathrm{M}+\mathrm{H}]^{+}$.

O-[N-(tert-Butoxycarbonyl)valylprolylvalyl]acetaminophen (7): According to the coupling procedure described for compound 3 , a solution of $6(300 \mathrm{mg}, 0.82 \mathrm{mmol})$ in $\mathrm{CH}_{2} \mathrm{Cl}_{2}(7 \mathrm{~mL})$ was treated with Boc-Val-Pro-OH $\quad(310 \mathrm{mg}, 0.99 \mathrm{mmol})$, BOP $\quad(437 \mathrm{mg}$, $0.99 \mathrm{mmol})$, and TEA $(0.25 \mathrm{~mL}, 1.81 \mathrm{mmol})$. The reaction mixture was stirred at RT for $15 \mathrm{~h}$, then the solvent was evaporated to dryness. The final residue was purified by CCTLC using the Chromatotron $\left(\mathrm{CH}_{2} \mathrm{Cl}_{2} / \mathrm{CH} 3 \mathrm{OH}, 40: 1\right)$ to yield 7 as a white foam $(417 \mathrm{mg}$, $97 \%$ yield): ${ }^{1} \mathrm{H}$ NMR (300 MHz, [ $\mathrm{D}_{6}$ ]acetone): $\delta=0.92-1.12(\mathrm{~m}, 12 \mathrm{H})$, $1.40(\mathrm{~s}, 9 \mathrm{H}), 2.07(\mathrm{~s}, 3 \mathrm{H}), 1.95-2.30(\mathrm{~m}, 6 \mathrm{H}), 3.70-3.79(\mathrm{~m}, 2 \mathrm{H}), 4.23$ $(\mathrm{m}, 1 \mathrm{H}), 4.52(\mathrm{~m}, 1 \mathrm{H}), 4.61(\mathrm{~m}, 1 \mathrm{H}), 5.83(\mathrm{~d}, J=7.5 \mathrm{~Hz}, 1 \mathrm{H}), 7.03$ and $7.66\left(\mathrm{AA}^{\prime} \mathrm{BB}^{\prime}\right.$ system, $\left.J=8.8 \mathrm{~Hz}, 4 \mathrm{H}\right), 7.68(\mathrm{~m}, 1 \mathrm{H}), 9.22 \mathrm{ppm}(\mathrm{s}$, 
$1 \mathrm{H}) ;{ }^{13} \mathrm{C}$ NMR (75 MHz, [D $]$ ]acetone): $\delta=19.119 .5,20.5,20.8,25.2$, 26.7, 29.6, 30.0, 32.5, 32.7, 49.2, 58.9, 59.7, 61.4, 80.0, 121.6, 123.5, 139.3, 148.0, 157.5, 169.8, 172.1, 173.2, $173.5 \mathrm{ppm} ; \mathrm{MS}\left(\mathrm{ESI}^{+}\right): \mathrm{m} / \mathrm{z}$ $547.3[\mathrm{M}+\mathrm{H}]^{+}, 569.3[\mathrm{M}+\mathrm{Na}]^{+}$; anal. calcd for $\mathrm{C}_{28} \mathrm{H}_{42} \mathrm{~N}_{4} \mathrm{O}_{7}: \mathrm{C} 61.52$, H 7.74, N 10.25; found: C 61.75, H 7.70, N 10.21.

O-(Valylprolylvalyl)acetaminophen trifluoroacetate (8): TFA $(0.56 \mathrm{~mL}, 7.35 \mathrm{mmol})$ was added to a solution of 7 (402 mg, $0.74 \mathrm{mmol})$ in $\mathrm{Et}_{2} \mathrm{O}(10 \mathrm{~mL})$, and the resulting reaction mixture was stirred at RT for $4 \mathrm{~h}$. The solvent was eliminated in vacuo and the residue was precipitated in $\mathrm{Et}_{2} \mathrm{O}$ to give 8 as a white solid $(403 \mathrm{mg}$, $98 \%$ yield); $\mathrm{mp}: 111-112^{\circ} \mathrm{C}\left(\mathrm{Et}_{2} \mathrm{O}\right) ;{ }^{1} \mathrm{H}$ NMR $\left(300 \mathrm{MHz},\left[\mathrm{D}_{6}\right] \mathrm{DMSO}\right)$ : $\delta=0.82-1.05(\mathrm{~m}, 12 \mathrm{H}), 2.03(\mathrm{~s}, 3 \mathrm{H}), 1.77-2.35(\mathrm{~m}, 6 \mathrm{H}), 3.45-3.76$ $(\mathrm{m}, 2 \mathrm{H}), 3.92(\mathrm{~d}, J=8.4 \mathrm{~Hz}, 1 \mathrm{H}), 4.29(\mathrm{t}, J=7.5 \mathrm{~Hz}, 1 \mathrm{H}), 4.52(\mathrm{~m}$, $1 \mathrm{H}), 6.99$ and $7.55\left(\mathrm{AA}^{\prime} \mathrm{BB}^{\prime}\right.$ system, $\left.J=8.8 \mathrm{~Hz}, 4 \mathrm{H}\right), 8.47(\mathrm{~d}, J=$ $7.5 \mathrm{~Hz}, 1 \mathrm{H}), 10.04 \mathrm{ppm}(\mathrm{s}, 1 \mathrm{H}) ;{ }^{13} \mathrm{C}$ NMR $\left(75 \mathrm{MHz},\left[\mathrm{D}_{6}\right] \mathrm{DMSO}\right): \delta=$ 17.1 18.1, 18.3, 19.0, 23.8, 24.6, 29.1, 29.3, 30.0, 47.4, 55.6, 57.4, 59.0, 119.9, 121.5, 137.1, 145.3, 166.5, 168.2, 170.3, 171.6 ppm; MS $\left(\mathrm{ESI}^{+}\right): \mathrm{m} / \mathrm{z} 447.3[\mathrm{M}+\mathrm{H}]^{+}, 469.3[\mathrm{M}+\mathrm{Na}]^{+}$; anal. calcd for $\mathrm{C}_{25} \mathrm{H}_{35} \mathrm{~F}_{3} \mathrm{~N}_{4} \mathrm{O}_{7}$ : C 53.57, H 6.29, N 9.99; found: C 53.73, H 6.17, N 10.03 .

$O$-[N-(9-Fluorenylmethoxycarbonyl)valyl]-(R/S)-propranolol (9a): Following a procedure similar to that described for compound 3 , a suspension of racemic propranolol hydrochloride $(300 \mathrm{mg}$, $1.01 \mathrm{mmol})$ in $\mathrm{CH}_{2} \mathrm{Cl}_{2}(10 \mathrm{~mL})$ was combined with Fmoc-Val-OH (344 mg, $1.01 \mathrm{mmol})$, BOP (449 mg, $1.01 \mathrm{mmol})$, and TEA $(0.311 \mathrm{~mL}$, $2.23 \mathrm{mmol})$. The reaction mixture was stirred at $0^{\circ} \mathrm{C}$ for $30 \mathrm{~min}$, then at RT for $15 \mathrm{~h}$. The final residue was purified by flash chromatography $\left(\mathrm{CH}_{2} \mathrm{Cl}_{2} / \mathrm{CH}_{3} \mathrm{OH}, 30: 1\right)$ to give a mixture of diastereomers 9a as a white foam $(475 \mathrm{mg}, 81 \%$ yield). Analytical data for the diastereomeric mixture: ${ }^{1} \mathrm{H}$ NMR $\left(300 \mathrm{MHz},\left[\mathrm{D}_{6}\right.\right.$ ]acetone): $\delta=0.91-$ $1.08(\mathrm{~m}, 24 \mathrm{H}), 2.00-2.05(\mathrm{~m}, 2 \mathrm{H}), 2.11-2.30(\mathrm{~m}, 2 \mathrm{H}), 2.76-2.85(\mathrm{~m}$, $2 \mathrm{H}), 2.89-3.21(\mathrm{~m}, 4 \mathrm{H}), 4.13-4.44(\mathrm{~m}, 12 \mathrm{H}), 5.47-5.58(\mathrm{~m}, 2 \mathrm{H})$, 6.89-6.91 (m, 2H), 7.24-7.50 (m, 18H), 7.60-7.70 (m, 4H), 7.75-7.84 $(\mathrm{m}, 6 \mathrm{H}), 8.19-8.22 \mathrm{ppm}(\mathrm{m}, 2 \mathrm{H}) ; \mathrm{MS}\left(\mathrm{ESI}^{+}\right): 581.3 \mathrm{~m} / \mathrm{z}[\mathrm{M}+\mathrm{H}]^{+}$ $603.3[\mathrm{M}+\mathrm{Na}]^{+}$; anal. calcd for $\mathrm{C}_{36} \mathrm{H}_{40} \mathrm{~N}_{2} \mathrm{O}_{5}: \mathrm{C} 74.46, \mathrm{H}$ 6.94, N 4.82; found: C 74.15, H 6.99, N 4.87.

$\mathrm{O}$-[N-(tert-Butoxycarbonyl)valyl]-(R/S)-propranolol (9 b): Following a similar coupling procedure to that described for compound $\mathbf{3}$, racemic propranolol hydrochloride $(400 \mathrm{mg}, 1.35 \mathrm{mmol})$ in $\mathrm{CH}_{2} \mathrm{Cl}_{2}$ $(10 \mathrm{~mL})$ was combined with Boc-Val-OH $(294 \mathrm{mg}, 1.35 \mathrm{mmol})$ in the presence of BOP $(598 \mathrm{mg}, 1.35 \mathrm{mmol})$ and TEA $(0.415 \mathrm{~mL}$, $2.97 \mathrm{mmol}$ ). The final residue was purified by flash chromatography $\left(\mathrm{CH}_{2} \mathrm{Cl}_{2} / \mathrm{CH}_{3} \mathrm{OH}, 35: 1\right)$ to provide the mixture of diastereomers $\mathbf{9} \mathbf{b}$ as a yellow foam $(440 \mathrm{mg}, 71 \%$ yield). Analytical data for the diastereomeric mixture: ${ }^{1} \mathrm{H}$ NMR (300 MHz, [ $\left.\mathrm{D}_{6}\right]$ acetone): $\delta=0.90-1.10$ $(\mathrm{m}, 24 \mathrm{H}), 1.39-1.41(\mathrm{~m}, 18 \mathrm{H}), 2.12-2.28(\mathrm{~m}, 2 \mathrm{H}), 2.82-3.16(\mathrm{~m}, 6 \mathrm{H})$ 4.07-4.16 (m, 2H), 4.34-4.48 (m, 4H), 5.45-5.56 (m, 2H), 6.15-6.23 $(\mathrm{m}, 2 \mathrm{H}), 6.95-6.98(\mathrm{~m}, 2 \mathrm{H}), 7.38-7.54(\mathrm{~m}, 8 \mathrm{H}), 7.83-7.86(\mathrm{~m}, 2 \mathrm{H})$ $8.22-8.27 \mathrm{ppm}(\mathrm{m}, 2 \mathrm{H}) ;{ }^{13} \mathrm{C}$ NMR $\left(100 \mathrm{MHz},\left[\mathrm{D}_{6}\right.\right.$ ]acetone): $\delta=18.3$, $18.6,19.5,19.6,22.9,23.1,23.3,28.5,28.6,31.3,31.4,47.8,47.9$, $49.3,49.6,60.5,68.9,73.3,73.4,79.3,79.4,105.8,105.9,121.3$, $122.8,122.9,126.0,126.1,126.4,126.5,126.9,127.3,128.3,135.6$, 155.2, 155.3, 156.8, 172.4, 172.9 ppm; MS $\left(\mathrm{ESI}^{+}\right): \mathrm{m} / \mathrm{z} 459.3[\mathrm{M}+$ $\mathrm{H}]^{+}, 481.3[\mathrm{M}+\mathrm{Na}]^{+}$; anal. calcd for $\mathrm{C}_{26} \mathrm{H}_{38} \mathrm{~N}_{2} \mathrm{O}_{5}: \mathrm{C} 68.10, \mathrm{H} 8.35, \mathrm{~N}$ 6.11; found: C 68.42, H 8.40, N 6.15.

O-Valyl-(R/S)-propranolol dihydrochloride (10): A $2 \mathrm{~N}$ solution of $\mathrm{HCl}$ in EtOAc $(0.5 \mathrm{~mL}, 0.99 \mathrm{mmol})$ was added to a solution of $\mathbf{9 b}$ $(152 \mathrm{mg}, 0.33 \mathrm{mmol})$ in EtOAc $(1 \mathrm{~mL})$ was added. The resulting reaction mixture was stirred at RT for $4 \mathrm{~h}$. The solvent was eliminated in vacuo and the residue was precipitated in $\mathrm{Et}_{2} \mathrm{O}$ to obtain the mixture of diastereomers 10 as a white solid (136 mg, $95 \%$ yield).
Analytical data for the diastereomeric mixture: $\mathrm{mp}: 105-106^{\circ} \mathrm{C}$ $\left(\mathrm{Et}_{2} \mathrm{O}\right) ;{ }^{1} \mathrm{H}$ NMR (300 MHz, $\left.\left[\mathrm{D}_{6}\right] \mathrm{DMSO}\right): \delta=0.83-0.92(\mathrm{~m}, 12 \mathrm{H}), 1.33-$ $1.37(\mathrm{~m}, 12 \mathrm{H}), 2.19-2.24(\mathrm{~m}, 2 \mathrm{H}), 3.37-3.51(\mathrm{~m}, 6 \mathrm{H}), 3.95-3.99(\mathrm{~m}$, $2 \mathrm{H}), 4.35-4.48(\mathrm{~m}, 4 \mathrm{H}), 5.78-5.86(\mathrm{~m}, 2 \mathrm{H}), 6.96-6.99(\mathrm{~m}, 2 \mathrm{H}), 7.39-$ $7.50(\mathrm{~m}, 8 \mathrm{H}), 7.83-7.86(\mathrm{~m}, 2 \mathrm{H}), 8.10-8.19(\mathrm{~m}, 2 \mathrm{H}), 8.87-9.11(\mathrm{~m}$, $6 \mathrm{H}), 9.51 \mathrm{ppm}(\mathrm{bm}, 4 \mathrm{H}) ;{ }^{13} \mathrm{C} \mathrm{NMR}\left(75 \mathrm{MHz},\left[\mathrm{D}_{6}\right] \mathrm{DMSO}\right): \delta=17.3$, $17.5,17.9,18.0,18.3,18.5,18.6,28.9,29.3,44.2,50.4,50.6,57.8$, $58.1,67.2,67.4,69.8,70.0,105.1,105.2,120.5,121.4,121.7,124.5$, 125.1, 125.2, 126.0, 126.5, 127.3, 127.4, 133.9, 153.1, 153.2, 166.3, $168.5 \mathrm{ppm} ; \mathrm{MS}\left(\mathrm{ESI}^{+}\right): \mathrm{m} / z 359.2[\mathrm{M}+\mathrm{H}]^{+}, 381.2[\mathrm{M}+\mathrm{Na}]^{+}$; anal. calcd for $\mathrm{C}_{21} \mathrm{H}_{32} \mathrm{Cl}_{2} \mathrm{~N}_{2} \mathrm{O}_{3}$ : C 58.47, $\mathrm{H} 7.48, \mathrm{~N} 6.49$; found: $\mathrm{C} 58.60, \mathrm{H}$ $7.53, \mathrm{~N} 6.54$.

O-[N-(tert-Butoxycarbonyl)valylprolylvalyl]-(R/S)-propranolol (11): A solution of 10 (178 mg, $0.42 \mathrm{mmol})$ in $\mathrm{CH}_{2} \mathrm{Cl}_{2}(5 \mathrm{~mL})$ was combined with Boc-Val-Pro-OH $(156 \mathrm{mg}, 0.50 \mathrm{mmol}), \mathrm{BOP}(220 \mathrm{mg}$, $0.50 \mathrm{mmol})$, and TEA $(0.185 \mathrm{~mL}, 1.33 \mathrm{mmol})$ according to the procedure described for compound 3 . The final residue was purified by CCTLC using the Chromatotron $\left(\mathrm{CH}_{2} \mathrm{Cl}_{2} / \mathrm{CH}_{3} \mathrm{OH}, 35: 1\right)$ to afford the mixture of diastereomers $\mathbf{1 1}$ as a white foam (195 mg, $72 \%$ yield). Analytical data for the diastereomeric mixture $(A+B)$ : ${ }^{1} \mathrm{H} N M R$ (300 MHz, [D $]$ acetone): $\delta=0.90-1.08(\mathrm{~m}, 36 \mathrm{H}), 1.40(\mathrm{~s}, 18 \mathrm{H}), 1.88-$ $2.17(\mathrm{~m}, 12 \mathrm{H}), 2.85-2.92(\mathrm{~m}, 2 \mathrm{H}), 3.02-3.11(\mathrm{~m}, 4 \mathrm{H}), 3.54-3.79(\mathrm{~m}$, $4 \mathrm{H}), 4.19-4.21(\mathrm{~m}, 2 \mathrm{H}), 4.29-4.61(\mathrm{~m}, 8 \mathrm{H}), 5.49-5.54(\mathrm{~m}, 2 \mathrm{H}), 6.95-$ $6.97(\mathrm{~m}, 2 \mathrm{H}), 7.37-7.53(\mathrm{~m}, 8 \mathrm{H}), 7.83-7.85(\mathrm{~m}, 2 \mathrm{H}), 8.22-8.24 \mathrm{ppm}$ (m, 2H); ${ }^{13} \mathrm{C}$ NMR $\left(100 \mathrm{MHz},\left[\mathrm{D}_{6}\right]\right.$ acetone): $\delta=18.8,19.1,19.2,20.1$, 20.5, 23.4, 23.6, 23.7, 26.3, 26.4, 29.2, 29.5, 29.6, 32.0, 32.2, 32.3 $48.2,48.3,48.8,48.9,50.0,50.1,58.5,58.6,59.6,61.0,61.4,69.6$, $73.9,74.1,79.7,106.3,106.4,121.9,123.5,126.6,126.7,127.1,127.5$, $127.9,128.9,136.2,155.8,157.2,172.3,172.8,173.1 \mathrm{ppm} ; \mathrm{MS}\left(\mathrm{ESI}^{+}\right)$: $\mathrm{m} / \mathrm{z} 655.3[\mathrm{M}+\mathrm{H}]^{+}, 677.3[\mathrm{M}+\mathrm{Na}]^{+}$; anal. calcd for $\mathrm{C}_{36} \mathrm{H}_{54} \mathrm{~N}_{4} \mathrm{O}_{7}: \mathrm{C}$ 66.03, H 8.31, N 8.56; found: C 65.86, H 8.37, N 8.61.

O-(Valylprolylvalyl)-(R/S)-propranolol dihydrochloride (12): Following the deprotection procedure described for compound 10, a solution of $11(161 \mathrm{mg}, 0.25 \mathrm{mmol})$ in EtOAc $(1 \mathrm{~mL})$ was treated with a $2 \mathrm{~N}$ solution of $\mathrm{HCl}$ in EtOAc $(0.38 \mathrm{~mL}, 0.75 \mathrm{mmol})$ for $3 \mathrm{~h}$. The final residue was precipitated in $\mathrm{Et}_{2} \mathrm{O}$, obtaining the mixture of diastereomers 12 as a white solid $(146 \mathrm{mg}, 95 \%$ yield). Analytical data for the diastereomeric mixture: $\mathrm{mp}: 131-133^{\circ} \mathrm{C}\left(\mathrm{Et}_{2} \mathrm{O}\right)$; ${ }^{1} \mathrm{H}$ NMR (300 MHz, [D $\mathrm{D}_{6}$ DMSO): $\delta=0.78-0.99(\mathrm{~m}, 24 \mathrm{H}), 1.31-1.39$ $(\mathrm{m}, 12 \mathrm{H}), 1.68-1.87(\mathrm{~m}, 6 \mathrm{H}), 1.93-2.20(\mathrm{~m}, 6 \mathrm{H}), 3.20-3.46(\mathrm{~m}, 6 \mathrm{H}$, $2 \mathrm{CH}), 3.68-3.73(\mathrm{~m}, 4 \mathrm{H}), 3.92-3.94(\mathrm{~m}, 2 \mathrm{H}), 4.22-4.61(\mathrm{~m}, 8 \mathrm{H})$, 5.63-5.65 (m, 2H), 6.97-6.99 (m, 2H), 7.41-7.53 (m, 8H), 7.86-7.89 $(\mathrm{m}, 2 \mathrm{H}), 8.11-8.18(\mathrm{~m}, 8 \mathrm{H}), 8.65$ and $8.73(2 \mathrm{~d}, J=8.7,8.4 \mathrm{~Hz}, 2 \mathrm{H})$, 9.17-9.52 ppm (bm, 4H); ${ }^{13} \mathrm{C}$ NMR (100 MHz, [D $]$ DMSO): $\delta=18.0$ $18.3,18.8,18.9,19.1,19.4,19.6,25.3,25.4,29.9,30.1,30.9,31.1$, $44.2,44.4,48.2,50.9,51.0,56.2,57.4,58.7,60.0,60.2,67.8,69.4$, $69.6,105.8,105.9,121.2,122.1,122.2,125.3,126.0,126.8,127.2$, $128.1,128.2,134.6,154.0,167.1,167.2,170.6,171.5,172.2$ ppm; MS $\left(\mathrm{ESI}^{+}\right): \mathrm{m} / \mathrm{z} 555.5[\mathrm{M}+\mathrm{H}]^{+}, \quad 577.5[\mathrm{M}+\mathrm{Na}]^{+}$; anal. calcd for $\mathrm{C}_{31} \mathrm{H}_{48} \mathrm{Cl}_{2} \mathrm{~N}_{4} \mathrm{O}_{5}$ : C 59.32, H 7.71, N 8.93; found: C 59.59, H 7.73, N 9.00 .

20-O-[N-(tert-Butoxycarbonyl)-L/D-valyl]camptothecin (13): $N, N^{\prime}$ diisopropylcarbodiimide $(88.0 \mu \mathrm{L}, 0.56 \mathrm{mmol})$ was added to a solution of Boc-Val-OH (248 mg, $1.12 \mathrm{mmol})$ in $\mathrm{CH}_{2} \mathrm{Cl}_{2}(6 \mathrm{~mL})$ cooled to $0{ }^{\circ} \mathrm{C}$. After stirring for $10 \mathrm{~min}$ at $0{ }^{\circ} \mathrm{C}$, the reaction was warmed to $\mathrm{RT}$ and stirred for an additional $10 \mathrm{~min}$. A few drops of DMF (to dissolve the formed precipitate) and DMAP $(72 \mathrm{mg}, 0.56 \mathrm{mmol})$ were added. The anhydride was added to a sealed microwave vessel containing a solution of camptothecin $(200 \mathrm{mg}, 0.56 \mathrm{mmol})$ in $\mathrm{CH}_{2} \mathrm{Cl}_{2}(6 \mathrm{~mL})$, and the vessel was heated in a microwave reactor at $80^{\circ} \mathrm{C}$ for $1 \mathrm{~h}$. Four subsequent additions of freshly prepared anhydride were needed to acquire completion of the reaction. After 
cooling, the solvent was evaporated to dryness, and the residue was dissolved in EtOAc $(20 \mathrm{~mL})$, washed with $10 \%$ aqueous citric acid $(3 \times 10 \mathrm{~mL}), 10 \%$ aqueous $\mathrm{NaHCO}_{3}(3 \times 10 \mathrm{~mL}), \mathrm{H}_{2} \mathrm{O}(3 \times 10 \mathrm{~mL})$, and brine $(3 \times 10 \mathrm{~mL})$. The organic layer was dried $\left(\mathrm{Na}_{2} \mathrm{SO}_{4}\right)$, filtered, and evaporated to dryness. The epimeric ratio of L-valine/D-valine was 1:1 as assessed by ${ }^{1} \mathrm{H}$ NMR analysis of the crude product. The final residue was purified by flash chromatography $\left(\mathrm{CHCl}_{3} / \mathrm{CH}_{3} \mathrm{OH}\right.$, 25:1) to yield a $1: 1$ mixture of diastereomers 13 as a yellow oil (160 mg, 51\% yield). Analytical data for the diastereomeric mixture: ${ }^{1} \mathrm{H}$ NMR (300 MHz, [D $\mathrm{D}_{6}$ DMSO): $\delta=0.78-1.01(\mathrm{~m}, 18 \mathrm{H}), 1.36$ and $1.37(2 \mathrm{~s}, 18 \mathrm{H}), 1.82-2.16(\mathrm{~m}, 6 \mathrm{H}), 4.11-4.21(\mathrm{~m}, 1 \mathrm{H}), 4.31-4.41$ $(\mathrm{m}, 1 \mathrm{H}), 5.29$ and $5.43(2 \mathrm{~s}, 4 \mathrm{H}), 5.63$ and $5.65(2 \mathrm{~s}, 4 \mathrm{H}), 6.73$ and $6.79(2 \mathrm{~d}, J=8.5,8.1 \mathrm{~Hz}, 2 \mathrm{H}), 7.31(\mathrm{~s}, 2 \mathrm{H}), 7.68-7.73(\mathrm{~m}, 2 \mathrm{H}), 7.84-$ $7.89(\mathrm{~m}, 2 \mathrm{H}), 8.13$ and $8.17(2 \mathrm{~d}, J=8.3,8.7 \mathrm{~Hz}, 4 \mathrm{H}), 8.68$ and $8.70 \mathrm{ppm}(2 \mathrm{~s}, 2 \mathrm{H})$; $\mathrm{MS}\left(\mathrm{ESI}^{+}\right): \mathrm{m} / \mathrm{z} 548.5[\mathrm{M}+\mathrm{H}]^{+}$; anal. calcd for $\mathrm{C}_{30} \mathrm{H}_{33} \mathrm{~N}_{3} \mathrm{O}_{7}$ : C 65.80, H 6.07, N 7.67; found: C 65.69, H 6.23, N 7.88.

20-O-(L/D-Valyl)camptothecin hydrochloride (14): ${ }^{[25]}$ A solution of $13(112 \mathrm{mg}, 0.20 \mathrm{mmol})$ in a $1.25 \mathrm{~N}$ solution of $\mathrm{HCl}$ in $\mathrm{CH}_{3} \mathrm{OH}$ $(4.8 \mathrm{~mL}, 6.0 \mathrm{mmol})$ was stirred at RT for $5 \mathrm{~h}$. The solvent was then eliminated in vacuo to afford the mixture of diastereomers 14 as a yellow oil $(96 \mathrm{mg}, 97 \%$ yield). Analytical data of the diastereomeric mixture: 'H NMR (400 MHz, [D 6 DMSO): $\delta=0.85-1.11(\mathrm{~m}, 18 \mathrm{H})$, 2.03-2.27 (m, 6H), 4.12-4.22 (m, 2H), $5.33(2 \mathrm{~s}, 4 \mathrm{H}), 5.54(2 \mathrm{~s}, 4 \mathrm{H})$, $7.39(\mathrm{~s}, 2 \mathrm{H}), 7.74(\mathrm{t}, J=7.2 \mathrm{~Hz}, 2 \mathrm{H}), 7.86-7.90(\mathrm{~m}, 2 \mathrm{H}), 8.08-$ $8.17 \mathrm{ppm}(\mathrm{m}, 7 \mathrm{H}), 8.72(\mathrm{bs}, 5 \mathrm{H}) ; \mathrm{MS}\left(\mathrm{ESI}{ }^{+}\right): \mathrm{m} / \mathrm{z} 448.2[\mathrm{M}+\mathrm{H}]^{+}$.

20-O-[N-(tert-Butoxycarbonyl)valylprolyl-L/D-valyl)]camptothecin (15): Following a similar coupling procedure to that described for compound 3, a solution of $14(88 \mathrm{mg}, 0.18 \mathrm{mmol})$ in $\mathrm{CH}_{2} \mathrm{Cl}_{2}(4 \mathrm{~mL})$ was reacted with Boc-Val-Pro-OH $(68 \mathrm{mg}, 0.22 \mathrm{mmol})$ in the presence of BOP (104 mg, $0.24 \mathrm{mmol})$ and TEA $(64 \mu \mathrm{L}, 0.48 \mathrm{mmol})$. The final residue was purified by CCTLC using the Chromatotron $\left(\mathrm{CH}_{2} \mathrm{Cl}_{2} / \mathrm{CH}_{3} \mathrm{OH}, 20: 1\right)$ to give the mixture of diastereomers 15 as a yellow oil ( $86 \mathrm{mg}, 64 \%$ yield). Analytical data of the diastereomeric mixture: ${ }^{1} \mathrm{H}$ NMR (300 MHz, $\left.\left[\mathrm{D}_{6}\right] \mathrm{DMSO}\right): \delta=0.80-1.04(\mathrm{~m}, 30 \mathrm{H}), 1.36$ and $1.38(2 \mathrm{~s}, 18 \mathrm{H}), 1.70-2.22(\mathrm{~m}, 16 \mathrm{H}), 3.44-3.80(\mathrm{~m}, 4 \mathrm{H}), 3.96-$ $4.03(\mathrm{~m}, 2 \mathrm{H}), 4.19(\mathrm{dd}, J=5.3,6.4 \mathrm{~Hz}, 1 \mathrm{H}), 4.39-4.42(\mathrm{~m}, 1 \mathrm{H}), 4.50$ $(\mathrm{t}, J=5.9 \mathrm{~Hz}, 1 \mathrm{H}), 4.61-4.64(\mathrm{~m}, 1 \mathrm{H}), 5.30(\mathrm{~s}, 4 \mathrm{H}), 5.49(\mathrm{~s}, 4 \mathrm{H}), 6.75$ and $6.81(2 \mathrm{~d}, J=6.5,6.1 \mathrm{~Hz}, 2 \mathrm{H}), 7.11(\mathrm{~s}, 2 \mathrm{H}), 7.71-7.74(\mathrm{~m}, 2 \mathrm{H})$ 7.87-7.94 $(\mathrm{m}, 3 \mathrm{H}), 8.09$ and $8.14(2 \mathrm{~d}, J=6.4,5.5 \mathrm{~Hz}, 4 \mathrm{H}), 8.45(\mathrm{~d}$, $J=6.2 \mathrm{~Hz}, 1 \mathrm{H}), 8.70 \mathrm{ppm}(\mathrm{s}, 2 \mathrm{H}) ; \mathrm{MS}\left(\mathrm{ESI}^{+}\right): \mathrm{m} / \mathrm{z} 744.8[\mathrm{M}+\mathrm{H}]^{+}$; anal. calcd for $\mathrm{C}_{40} \mathrm{H}_{49} \mathrm{~N}_{5} \mathrm{O}_{9}$ : C 64.59, H 6.64, N 9.42; found: C 64.38, H 6.45, N 9.60.

20-O-(Valylprolyl-L/D-valyl)camptothecin hydrochloride (16): A solution of 15 (113 mg, $0.15 \mathrm{mmol})$ was combined in a $1.25 \mathrm{~N}$ solution of $\mathrm{HCl}$ in $\mathrm{CH}_{2} \mathrm{Cl}_{2}(3.0 \mathrm{~mL}, 3.75 \mathrm{mmol})$ and was stirred at $\mathrm{RT}$ for $4 \mathrm{~h}$. The solvent was eliminated in vacuo to provide the mixture of diastereomers 16 as a yellow oil (94 mg, $91 \%$ yield). Analytical data for the diastereomeric mixture: ${ }^{1} \mathrm{H}$ NMR $\left(300 \mathrm{MHz},\left[\mathrm{D}_{6}\right] \mathrm{DMSO}\right): \delta=$ $0.82-1.00(\mathrm{~m}, 30 \mathrm{H}), 1.71-2.35(\mathrm{~m}, 16 \mathrm{H}), 3.35-3.64(\mathrm{~m}, 4 \mathrm{H}), 3.94$ (bm, 2H), 4.22-4.26 (m, 1 H), 4.47-4.55 (m, 2H), 4.63-4.66 (m, 1 H), $5.29(\mathrm{~s}, 4 \mathrm{H}), 5.49(\mathrm{~s}, 4 \mathrm{H}), 7.08(\mathrm{~s}, 2 \mathrm{H}), 7.70-7.74(\mathrm{~m}, 2 \mathrm{H}), 7.86-7.90$ $(\mathrm{m}, 2 \mathrm{H}), 8.03-8.27(\mathrm{~m}, 11 \mathrm{H}), 8.59(\mathrm{~d}, J=6.5 \mathrm{~Hz}, 1 \mathrm{H}), 8.70 \mathrm{ppm}(\mathrm{s}$, $2 \mathrm{H}) ;{ }^{13} \mathrm{C}$ NMR $\left(100 \mathrm{MHz},\left[\mathrm{D}_{6}\right.\right.$ ]DMSO): $\delta=7.7,7.8,17.1,17.5,18.1$, $18.2,18.4,19.0,19.3,19.5,23.5,24.9,25.1,29.4,29.6,30.6,30.8$, $35.2,36.9,40.8,47.7,50.4,53.4,55.7,57.7,59.4,66.6,67.4,76.0$, $76.2,76.9,95.0,119.2,119.3,119.5,127.9,128.1,128.8,128.9,130.0$, 130.6, 131.8, 144.7, 146.1, 148.0, 152.5, 152.6, 156.6, 166.7, 167.0, 169.9, 170.9, $171.7 \mathrm{ppm}$; $\mathrm{MS}\left(\mathrm{ESI}^{+}\right): \mathrm{m} / \mathrm{z} 644.3[\mathrm{M}+\mathrm{H}]^{+}$; anal. calcd for $\mathrm{C}_{35} \mathrm{H}_{42} \mathrm{CIN}_{5} \mathrm{O}_{7}$ : C 61.80, H 6.22, N 10.30; found: C 61.69, H 6.25, N 10.37 .
Water solubility studies: Water solubility of the prodrug of camptothecin 16 as well as the parent compound was determined by HPLC analysis. HPLC was carried out on a Waters 484 System using a Novapack $\mathrm{C} 18$ reverse phase column (flow rate: $1 \mathrm{~mL} \mathrm{~min}^{-1}$; detection: UV $254 \mathrm{~nm}$; gradient solvent system $A / B\left(\mathrm{CH}_{3} \mathrm{CN} / \mathrm{H}_{2} \mathrm{O}\right)$ : initial $15 \% A+85 \% B$; 5 min linear gradient to $25 \% A+75 \% B$; 5 min linear gradient to $35 \% A+65 \% B ; 10$ min linear gradient to $45 \% \mathrm{~A}+55 \% \mathrm{~B} ; 5$ min linear gradient to $60 \% \mathrm{~A}+40 \% \mathrm{~B}$, and 5 min linear gradient to $100 \% \mathrm{~A}$ ). An excess amount of the prodrug or the parent drug was suspended in PBS at pH 7.4 or $\mathrm{pH} 5.0$, sonicated for $10 \mathrm{~min}$ at room temperature, then equilibrated overnight at room temperature. The samples were centrifuged at $14000 \mathrm{rpm}$ in an Eppendorf microcentrifuge for $1.5 \mathrm{~min}$ at room temperature. An aliquot of the clear supernatant was removed and diluted to a concentration within the range of a five-point standard curve. Water solubility was calculated from each peak area of the above solution by HPLC as compared with a sample of known concentration dissolved in acetonitrile.

\section{Biological methods}

Compounds and enzymes: Soluble human DPPIV/CD26 was purified as described ${ }^{[33]}$ or was obtained from Sigma-Aldrich. Fetal bovine serum was obtained from Integro, and human serum was provided by the Blood Bank, Leuven, Belgium.

Conversion of peptidyl prodrugs to the corresponding parent compound: The test compounds were evaluated for their substrate activity against purified DPPIV/CD26, human serum (HS), and bovine serum (BS) in Eppendorf tubes. The $400 \mu \mathrm{L}$ reaction mixtures contained $50 \mu \mathrm{M}$ test compound in PBS (pH 7.6) containing $0.1 \%$ DMSO. The reaction was initiated by the addition of purified DPPIV/CD26 (1.5 mU) or $20 \%$ of HS (in PBS) or BS (in PBS) at $37^{\circ} \mathrm{C}$. The experiments were performed in PBS containing $20 \% \mathrm{HS}$ or BS to buffer the sera at $\mathrm{pH} 7.6$ and to ensure that prodrug conversion could be followed over a reasonable time period. Human serum was chosen for its relevance to clinically used drugs, and bovine serum was chosen because of its relevance in cell culture-based assays that contain $20 \%$ BS. At various time points as indicated in the figures, $100 \mu \mathrm{L}$ was withdrawn from the reaction mixture, added to $200 \mu \mathrm{L}$ of cold $\mathrm{CH}_{3} \mathrm{OH}$, and incubated on ice for $10 \mathrm{~min}$. The mixtures were centrifuged at $13000 \mathrm{rpm}$ for $5 \mathrm{~min}$ at $4{ }^{\circ} \mathrm{C}$, and $250 \mu \mathrm{L}$ supernatant was analyzed by HPLC on a reverse phase RP-8 column using the following buffers and gradients: buffer $A: 50 \mathrm{~mm}$ $\mathrm{NaH}_{2} \mathrm{PO}_{4}+5 \mathrm{~mm}$ heptanesulfonic acid, $\mathrm{pH} 3.2$; buffer B: acetonitrile; gradient: 2 min $98 \% A+2 \% B$; 6 min linear gradient to $80 \%$ $A+20 \% B ; 2$ min linear gradient to $75 \% A+25 \% B ; 2$ min linear gradient to $65 \% A+35 \% B ; 18$ min linear gradient to $50 \% A+$ $50 \% \mathrm{~B} ; 5$ min $50 \% \mathrm{~A}+50 \% \mathrm{~B} ; 5$ min linear gradient to $98 \% \mathrm{~A}+$ $2 \% B ; 5$ min equilibration at $98 \% A+2 \%$ B. These gradients allowed separation of the tripeptidyl compound prodrugs from the corresponding metabolites and parent compounds.

\section{Acknowledgements}

We thank the Spanish MEC/MICINN (project SAF2009-13914-C02), the Comunidad de Madrid (project BIPEDD-CM ref. S-BIO-02142006), and the KU Leuven (GOA no. 10/014) for financial support. Postdoctoral fellowship to S.C. awarded by the Spanish Ministry of Science and Innovation (JDC-MICINN) is gratefully acknowledged. We also thank Mrs. Ria Van Berwaer and Mrs. Lizette van Berckelaer for excellent technical assistance. 
Keywords: CD26 • dipeptidyl peptidase IV • hydroxycontaining drugs $\cdot$ peptides $\cdot$ prodrugs

[1] C. G. Wermuth, The Practice of Medicinal Chemistry, 2nd ed., Academic Press, London, 2003, pp. $561-582$.

[2] Prodrugs: Challenges and Rewards (Eds.: V. J. Stella, R. T. Borchardt, M. J. Hageman, R. Oliyai, H. Maag, J.W. Tilley), AAPS Press, Springer, New York, 2007.

[3] J. Rautio, H. Kumpulainen, T. Heimbach, R. Oliyai, D. Oh, T. Järvinen, J. Savolainen, Nat. Rev. Drug. Discovery 2008, 7, 255-270.

[4] a) L. Colla, E. De Clercq, R. Busson, H. Vanderhaeghe, J. Med. Chem. 1983, 26, 602-604; b) L. M. Beauchamp, G. F. Orr, P. de Miranda, T. Burnette, T. A. Krenitsky, Antiviral Chem. Chemother. 1992, 3, 157-164; C) K. R. Beutner, Antiviral Res. 1995, 28, 281-290; d) C. MacDougall, B. J. Guglielmo, J. Antimicrob. Chemother. 2004, 53, 899-901.

[5] J. M. Cocohoba, I. R. McNicholl, Ann. Pharmacother. 2002, 36, $1075-$ 1079.

[6] C. McGuigan, R. N. Pathirana, M. Migliore, R. Adak, G. Luoni, A. T. Jones, A. Diez-Torrubia, M.-J. Camarasa, S. Velázquez, G. Henson, E. Verbeken, R. Sienaert, L. Naesens, R. Snoeck, G. Andrei, J. Balzarini, J. Antimicrob. Chemother. 2007, 60, 1316-1330.

[7] a) M. E. Ganapathy, W. Huang, V. Ganapathy, F. H. Leibach, Biochem. Biophys. Res. Commun. 1998, 246, 470-475; b) H. Han, R. L. A. de Vrueh J. K. Rhie, K. Y. Covitz, P. L. Smith, C. Lee, D. Oh, W. Sadée, G. L. Amidon, Pharm. Res. 1998, 15, 1154-1159; c) M. Sugawara, W. Huang, Y.-J. Fei, F. H. Leibach, V. Ganapathy, M. E. Ganapathy, J. Pharm. Sci. 2000, 89, $781-789$.

[8] B. M. Liederer, R. T. Borchardt, J. Pharm. Sci. 2006, 95, 1177-1195.

[9] a) I. De Meester, G. Vanhoof, A.-M. Lambeir, S. Scharpe, Immunol. Today 1999, 20, 367-375; b) A.-M. Lambeir, C. Durinx, S. Scharpe, I. De Meester, Crit. Rev. Clin. Lab. Sci. 2003, 40, 209-294.

[10] A. Yaron, F. Naider, Crit. Rev. Biochem. Mol. Biol. 1993, 28, 31-81.

[11] D. A. Fox, R. E. Hussey, K. A. Fitzgerald, O. Acuto, C. Poole, L. Palley, J. F. Daley, S. F. Schlossman, E. L. Reinherz, J. Immunol. 1984, 133, 1250 1256.

[12] R. Mentlein, Regul. Pept. 1999, 85, 9-24; R. Mentlein, Int. Rev. Cytol. 2004, 235, 165-202.

[13] J. Balzarini, E. Andersson, D. Schols, P. Proost, J. Van Damme, B. Svennerholm, P. Horal, A. Vahlne, Int. J. Biochem. Cell Biol. 2004, 36, 1848-1859.

[14] C. García-Aparicio, M.-C. Bonache, I. De Meester, A. San-Félix, J. Balzarini, M.-J. Camarasa, S. Velázquez, J. Med. Chem. 2006, 49, 5339-5351.

[15] C. García-Aparicio, A. Diez-Torrubia, J. Balzarini, A.-M. Lambeir, S. Velázquez, M.-J. Camarasa, Antiviral Res. 2007, 76, 130-139.

[16] A. Diez-Torrubia, C. García-Aparicio, S. Cabrera, I. De Meester, J. Balzarini, M.-J. Camarasa, S. Velázquez, J. Med. Chem. 2010, 53, 559-572.

[17] G. Vanhoof, F. Goossens, I. De Meester, D. Hendriks, S. Scharpé, FASEB J. 1995, 9, 736-744

[18] a) J. Balzarini, M. J. Pérez-Pérez, A. San-Félix, D. Schols, C. F. Perno, A. M. Vandamme, M. J. Camarasa, E. De Clercq, Proc. Natl. Acad. Sci. USA 1992, 89, 4392-4396; b) M. J. Camarasa, M. J. Pérez-Pérez, A. San-Félix, J. Balzarini, E. De Clercq, J. Med. Chem. 1992, 35, 2721-2727.

[19] a) M. J. Camarasa, A. San-Félix, M. J. Pérez-Pérez, S. Velázquez, R. Alvarez, C. Chamorro, M. L. Jimeno, C. Pérez, F. Gago, E. De Clercq, J. Balzarini, J. Carbohydr. Chem. 2000, 19, 451-469; b) M. J. Camarasa, A. San-Félix, S.
Velázquez, M. J. Pérez-Pérez, F. Gago, J. Balzarini, Curr. Top. Med. Chem. 2004, 4, 945-963.

[20] A. Diez-Torrubia, J. Balzarini, G. Andrei, R. Snoeck, I. De Meester, M.-J. Camarasa, S. Velázquez, J. Med. Chem. 2011, 54, 1927-1942.

[21] C. M. Perry, J. A. Balfour, Drugs 1996, 52, 928-962.

[22] L. Hansson, L. Werkö, Am. Heart J. 1977, 93, 394-402.

[23] a) Y. Pommier, Nat. Rev. Cancer 2006, 6, 789-802; b) V. J. Venditto, E. E. Simanek, Mol. Pharm. 2010, 7, 307-349.

[24] For hydrolysis of propranolol esters, see: A. Buur, H. Bundgaard, V. H. L. Lee, Int. J. Pharm. 1988, 42, 51-60.

[25] M. Deshmukh, P. Chao, H. L. Kutscher, D. Gao, P. J. Sinko, J. Med. Chem. 2010, 53, 1038-1047.

[26] H.-G. Lerchen, K. von dem Bruch, J. Prakt. Chem. 2000, 342, 753-760. This paper describes reduction in epimerization using urethane $\mathrm{N}$-carboxy-protected amino acid anhydrides under reflux conditions over long reaction times (2-4 days). Unfortunately, we were not able to Bocprotect the urethane amino acid. For other references of the acylation method using urethane-protected $\mathrm{N}$-carboxyanhydrides, see: a) W. D. Fuller, M. P. Cohen, M. Shabankareh, R. K. Blair, M. Goodman, F. R. Naider, J. Am. Chem. Soc. 1990, 112, 7414-7416; b) W. D. Fuller, M. Goodman, F. R. Naider, Y.-F. Zhu, Biopolymers 1996, 40, 183-205.

[27] Previous data (see references [9b] and [14]) show that DPPIV has an absolute requirement for the $S$ configuration in the $\mathrm{N}$-terminal penultimate proline residue, as this residue fits into a narrow pocket of the enzyme. However, no specific requirements for the third residue, which would correspond to L/D-Val linked to camptothecin in our target [ValPro]-[Val]-prodrugs, are expected based on the crystal structure of DPPIV in complex with a peptide substrate; see: K. Aertgeerts, S. Ye, M. G. Tennant, M. L. Kraus, J. Rogers, B. C. Sang, R. J. Skene, D. R. Webb, G. S. Prasad, Protein Sci. 2004, 13, 412-421. Moreover, we previously reported that a wide variety of [Val-Pro]-[drugs] were efficiently recognized as substrates by DPPIV (see references [14] and [16]), further supporting that this position is less strict in terms of structural requirements. Therefore, no substantial differences are expected between both diastereomers of target [Val-Pro]-[L/D-Val]-[camptothecin] 16.

[28] Our results complement previous studies on the instability of various aliphatic esters of propranolol in aqueous solutions (see reference [24]). However, in these studies, degradation of prodrugs involves not only ester hydrolysis but also intramolecular aminolysis, giving rise to $\mathrm{N}$-acylated propranolol derivatives that were not detected in our compounds.

[29] D. Darmoul, T. Voisin, A. Couvineau, C. Rouyer-Fessard, R. Salomon, Y. Wang, D. M. Swallow, M. Laburthe, Biochem. Biophys. Res. Commun. 1994, 203, 1224- 1229.

[30] T. Terada, K. Inui, Curr. Drug Metab. 2004, 5, 85-94.

[31] Z. Yan, J. Sun, Y. Chang, Y. Liu, Q. Fu, Y. Xu, Y. Sun, X. Pu, Y. Zhang, Y. Jing, S. Yin, M. Zhu, Y. Wang, Z. He, Mol. Pharm. 2011, 8, 319-329.

[32] C. Santos, M. L. Mateus, A. P. dos Santos, R. Moreira, E. de Oliveira, P. Gomes, Bioorg. Med. Chem. Lett. 2005, 15, 1595-1598.

[33] I. De Meester, G. Vanhoof, A.-M. Lambeir, S. Scharpé, J. Immunol. Methods $1996,189,99-105$.

Received: October 28, 2011

Revised: January 11, 2012

Published online on February 3, 2012 